OPEN ACCESS

Edited by:

Hai Xu,

Tianjin University, China

Reviewed by:

Zhiping Tian,

Institute of Atmospheric Physics

(CAS), China

Zhengguo Shi,

Institute of Earth Environment (CAS),

China

${ }^{*}$ Correspondence:

Xiaodong Ding

dingxd@nmu.edu.cn

Specialty section:

This article was submitted to Quaternary Science, Geomorphology and Paleoenvironment, a section of the journal Frontiers in Earth Science

Received: 10 March 2020 Accepted: 02 June 2020

Published: 30 July 2020

Citation:

Ding $X$, Zheng L, Zheng $X$ and Kao S-J (2020) Holocene East Asian Summer Monsoon Rainfall Variability

in Taiwan. Front. Earth Sci. 8:234.

doi: 10.3389/feart.2020.00234

\section{Holocene East Asian Summer Monsoon Rainfall Variability in Taiwan}

\author{
Xiaodong Ding ${ }^{1 *}$, Liwei Zheng ${ }^{2}$, Xufeng Zheng ${ }^{3}$ and Shuh-Ji Kao² \\ ${ }^{1}$ College of Biological Science \& Engineering, North Minzu University, Yinchuan, China, ${ }^{2}$ State Key Laboratory of Marine \\ Environmental Science, College of Ocean and Earth Sciences, Xiamen University, Xiamen, China, ${ }^{3}$ Key Laboratory \\ of Marginal Sea Geology, South China Sea Institute of Oceanology, Chinese Academy of Sciences, Guangzhou, China
}

Characterizing the spatiotemporal variability of the East Asian summer monsoon (EASM) advances our understanding of its rhythm, dynamics, and future impacts. East Asian summer monsoon variations during the Holocene have been reconstructed from a variety of geological archives and proxies. However, the spatiotemporal heterogeneity of EASM rainfall during the Holocene remains controversial. Taiwan is geographically suitable for studying the EASM history, through its geological archives. Herein, we synthesize the reported lake and peat sedimentary records of the entire Holocene, in addition to the records of mass-wasting and on-land deposition from cores collected from Taiwan to illustrate the EASM induced hydroclimate changes in Taiwan throughout the Holocene. Records from Taiwan indicate that the EASM rainfall maximum occurred during the early Holocene, concurring with other EASM records from monsoon regions in southern China. We suggest that the early Holocene EASM rainfall maximum in southern China was mainly forced by the higher Northern Hemisphere summer insolation and sea surface temperatures (SSTs) in the Western Pacific Warm Pool (WPWP). A synthesis of EASM rainfall records from across China shows that the timing of the Holocene EASM rainfall maximum occurred progressively later than that from southern to northern China. This time-transgressive EASM rainfall maximum may be due to the latitudinal shift of the westerlies and Western Pacific subtropical high (WPSH) that was induced by changes of interhemispheric temperature gradients $\left(\Delta T_{N-S}\right)$ and the northern high latitude ice volume. Moreover, records from Taiwan suggest a significant collapse of the EASM in Taiwan at $\sim 4-2$ ka BP. Based on the records from Taiwan, coastal East Asia, and the Tropical Pacific, we propose that the SSTs of the WPWP and/or El Niño-Southern Oscillation activity may have exerted a strong influence on the EASM rainfall changes during the late Holocene. Moreover, increased EASM rainfall in southern China during the last 2 ka was likely caused by a southward shift of WPSH, which is associated with gradual decreases in $\Delta T_{N-S}$ during the late Holocene.

Keywords: East Asian summer monsoon, Taiwan, Holocene, maximum rainfall, solar insolation, WPSH, ENSO 


\section{INTRODUCTION}

As an important component of the global atmospheric circulation system, the East Asian summer monsoon (EASM) plays a significant role in global hydrologic and energy cycles and is the primary driver of hydroclimatic changes in East Asia (Ding and Chan, 2005; An et al., 2015). Unlike the Indian summer monsoon, which consists of moisture sourced mainly from the Indian Ocean, the EASM is a combination of tropical and subtropical monsoon systems with complex moisture sources that include tropical sources in the Indian Ocean and the South China Sea, as well as subtropical sources in the western North Pacific (Ding and Chan, 2005; Wang et al., 2008). The EASM has a profound impact on the livelihood of people living in East Asia through the distribution of monsoon-related rainfall and any related disasters (e.g., floods, droughts, typhoons). It is vital to study the evolution of EASM variabilities on different timescales in order to understand their hemispheric and global teleconnections, possible forcing mechanisms, and future hydroclimatic changes.

The history of the EASM and its forcing mechanisms have been the subject of numerous paleoclimate studies. Various geological archives have been used to reconstruct the EASM history such as loess-paleosol sequences (An et al., 1990; Guo et al., 2000; Sun et al., 2006, 2015; Wang H. et al., 2014; Beck et al., 2018; Meng et al., 2018), lake and peat sediments (Zhou et al., 2004; Xiao et al., 2006; Selvaraj et al., 2007; Yancheva et al., 2007; Zhong et al., 2010; Chen F. et al., 2015; Park et al., 2016; Wang et al., 2016), marine sediments (Wang et al., 1999; Liu et al., 2003; Sun et al., 2003; Wan et al., 2010), and stalagmite records (Wang et al., 2001, 2005; Yuan et al., 2004; Dykoski et al., 2005; Cheng et al., 2009, 2016, 2019; Zhang et al., 2019). Among these, the stalagmite records have been widely used to reconstruct the variations in the EASM on different timescales due to their wide distribution, precise dating, and continuity over long timescales (Cheng et al., 2019). However, the paleoclimatic significance of the most important proxy obtained from stalagmites (stable oxygen isotopes; $\delta^{18} \mathrm{O}$ ) remains debated because of the complex relationship between local rainfall and $\delta^{18} \mathrm{O}$ in the EASM region (Maher, 2008; Pausata et al., 2011; Caley et al., 2014; Tan, 2014; Baker et al., 2015; Liu et al., 2015; Chen et al., 2016). It has been argued that the variabilities in the $\delta^{18} \mathrm{O}$ of Chinese stalagmites are more likely controlled by changes in the moisture source (Maher, 2008; Maher and Thompson, 2012) or the atmospheric moisture pathway (Baker et al., 2015), rather than by local rainfall amounts. In addition, Pausata et al. (2011) concluded that changes in the stalagmite $\delta^{18} \mathrm{O}$ records from China reflect changes in the intensity of the Indian rather than East Asian monsoon precipitation. However, by comparing simulations and observations from paleoclimatic records, Liu et al. (2014b) suggested that the stalagmite $\delta^{18} \mathrm{O}$ records are a robust proxy for the EASM intensity in terms of the southerly monsoon winds and monsoon rainfall in northern China. Moreover, a synthesized stalagmite $\delta^{18} \mathrm{O}$ record, which is based on 16 stalagmites from the EASM region of China, exhibits a Holocene EASM evolutionary pattern that is similar to other EASM records derived from the monsoonal region of China; this result confirms that the stalagmite $\delta^{18} \mathrm{O}$ records are a valid indicator of EASM intensity, rather than the local rainfall amount (Yang et al., 2019).

The spatiotemporal heterogeneity of EASM rainfall during the Holocene is also a debated issue (Shi et al., 2012; Xie et al., 2013; Chen F. et al., 2015; Jia et al., 2015; Rao et al., 2016; Zhou et al., 2016; Goldsmith et al., 2017; Zhu et al., 2017; Huang X. et al., 2018; Ming et al., 2020; Xu et al., 2020). For example, stalagmite $\delta^{18} \mathrm{O}$ records show an early Holocene EASM maximum (Dykoski et al., 2005; Wang et al., 2005; Cai et al., 2010; Dong et al., 2010; Zhang et al., 2019), which is also supported by lacustrine records from southern China (Zhou et al., 2004; Zhong et al., 2010; Wang et al., 2016; Sheng et al., 2017). However, numerous records from arid/semi-arid northern China show a middle Holocene EASM rainfall maximum (Lu et al., 2013; Wang and Feng, 2013; Li et al., 2014; Wang H. et al., 2014; Chen F. et al., 2015; Guo et al., 2018). By combining these records with the TraCE-21 ka transient simulation (Liu et al., 2009, 2014a). Lu et al. (2019) pointed out that the trend of the Holocene EASM rainfall in southern China $\left(28^{\circ}-38^{\circ} \mathrm{N}, 112^{\circ}-124^{\circ} \mathrm{E}\right)$ matched with the decreasing trend in the Northern hemisphere solar insolation (NHSI), while the maximum rainfall in arid/semiarid northern China $\left(38^{\circ}-53^{\circ} \mathrm{N}, 80^{\circ}-105^{\circ} \mathrm{E}\right)$ lags behind the peak insolation by $\sim 4-5 \mathrm{ka}$. By comparing the full and single forcing transient simulations, Lu et al. (2019) also suggested that the northern high latitude ice volume suppressed the summer rainfall in northern China, but had little effect on southern China during the early Holocene, leading to the meridional asynchronous evolution of the EASM rainfall amounts. Note that "southern China" as defined by Lu et al. (2019) is not the traditional view of what is actually "southern China." It is a region located around the middle to lower reaches of the Yangtze River. Recently, Xu et al. (2020) noted a very different pattern of the EASM in southern China, based on lake level reconstructions. According to their reconstructions, the summer monsoon rainfall in southern China was high during the early and late Holocene, but low during the middle Holocene (Xu et al., 2020). Such a pattern is also evident in subtropical East Asia $\left(20-27^{\circ} \mathrm{N}, 110-125^{\circ} \mathrm{E}\right)$ precipitation in the TraCE-21ka simulations (Xu et al., 2020). This pattern is also supported by several paleoclimate records from the middle Yangtze Valley which indicate wet conditions during the early and late Holocene, but dry conditions during the middle Holocene (Xie et al., 2013; Huang X. et al., 2018; Liu et al., 2019). However, these records are inconsistent with other proxy records from the same sites, including a pollen record from the Dajiuhu peatland (Zhu et al., 2010) and a stalagmite $\delta^{18} \mathrm{O}$ record from Heshang Cave (Hu et al., 2008). This discrepancy may exist for a number of reasons, such as climatic sensitivity of the different proxy indicators ( $\mathrm{Li}$ et al., 2018; Lu et al., 2019). However, pollen based quantitative rainfall reconstructions from the lower reaches of the Yangtze River show an early to middle Holocene (106 ka BP) EASM rainfall maximum (Li et al., 2018; Lu et al., 2019). These studies render the spatiotemporal evolution of the EASM rainfall elusive. Moreover, the early to middle Holocene has generally been characterized as a warm period (Renssen et al., 2012) and has thus been considered as a potential "analog" for modern climatic conditions. To better project any future changes 
of the EASM-related hydroclimate under a background of global warming, it is essential to comprehend the spatiotemporal variations of EASM rainfall during the Holocene and its possible forcing mechanisms.

Located at the front edge of the East Asian continent (Figure 1A), Taiwan's climate is heavily influenced by the EASM; therefore, it is a suitable location for exploring past EASM variability by studying the geological archives in its lakes and swamps (Liew et al., 2006, 2014; Selvaraj et al., 2007, 2011, 2012; Lee and Liew, 2010; Lee et al., 2010; Yang et al., 2011; Wang L.-C. et al., 2014; Wang et al., 1999; Ding et al., 2016, 2017). However, due to the high relief, steep topography, extreme rainfall, and landslides induced by frequent typhoon activity that lead to high erosion and sedimentation rates, climate archives from Taiwan are rarely long enough to cover the entire Holocene. To date, only three lake and peat sediment cores have been retrieved that cover the entire Holocene. These sediment cores originate from the Retreat Lake (northern Taiwan, $24^{\circ} 29^{\prime} \mathrm{N}$, $121^{\circ} 26^{\prime} \mathrm{E}$; $2230 \mathrm{~m}$ above sea level; Selvaraj et al., 2007), the Toushe Basin (central Taiwan, $23^{\circ} 49^{\prime} \mathrm{N} ; 120^{\circ} 53^{\prime} \mathrm{E}$; $650 \mathrm{~m}$ above sea level; Liew et al., 2006), and the Dongyuan Lake (southern Taiwan, $22^{\circ} 10^{\prime} \mathrm{N}, 120^{\circ} 50^{\prime} \mathrm{E}, 360 \mathrm{~m}$ above sea level; Lee et al., 2010; Figure 1B). In addition, Taiwan is a mountainous island characterized by active rock uplift, rapid fluvial bedrock incision, frequent seismic activity, and episodic extreme rainfall events, rendering it exposed to frequent landslides and debris flows that are observed almost annually (Hsieh and Chyi, 2010). The deposited gravel from ancient landslide and debris flows, and their associated landforms (e.g., alluvial terraces) can be used to reconstruct paleo-mass-wasting events that are likely related to climatic changes (Hsieh et al., 2011, 2014). The mass-wasting events have been traced back to $14.8 \mathrm{ka}$ using radiocarbon dating. Furthermore, Wu (2013) obtained a good record of the on-land depositional history during the Holocene by studying the 12 deep cores from the Lanyang Plain in northern Taiwan. In this study, we compiled data from all the three long sedimentary cores that covered the entire Holocene and combined them with the mass-wasting records and the depositional histories that were obtained from the on-land cores to illustrate the variability of EASM rainfall in Taiwan during the Holocene.

\section{Study Area}

The subtropical island of Taiwan is located off the southeastern coast of mainland China. Its climate is mainly influenced by the East Asian monsoon system, which has strong seasonal variabilities. Precipitation in Taiwan is influenced by the northeasterly monsoon during the cold season (SeptemberApril) and the southwesterly monsoon during the warm seasons (May-August) (Chen and Chen, 2003; Wang and Chen, 2008). The annual rainfall in Taiwan usually exceeds $2500 \mathrm{~mm}$ and can reach $3300 \mathrm{~mm}$ locally. More than 90\% of the total rainfall occurs during the summer season. In addition to the EASM rainfall, Taiwan is often threatened by episodic typhoons that have caused enormous loss of life and property. On average, approximately four typhoons hit Taiwan every year (Chen and Chen, 2003). According to the Taiwan Central Weather Bureau, ${ }^{1}$ the mean monthly temperature of Taiwan ranges from $14^{\circ} \mathrm{C}$ in January to $28^{\circ} \mathrm{C}$ in July.

${ }^{1}$ http://www.cwb.gov.tw
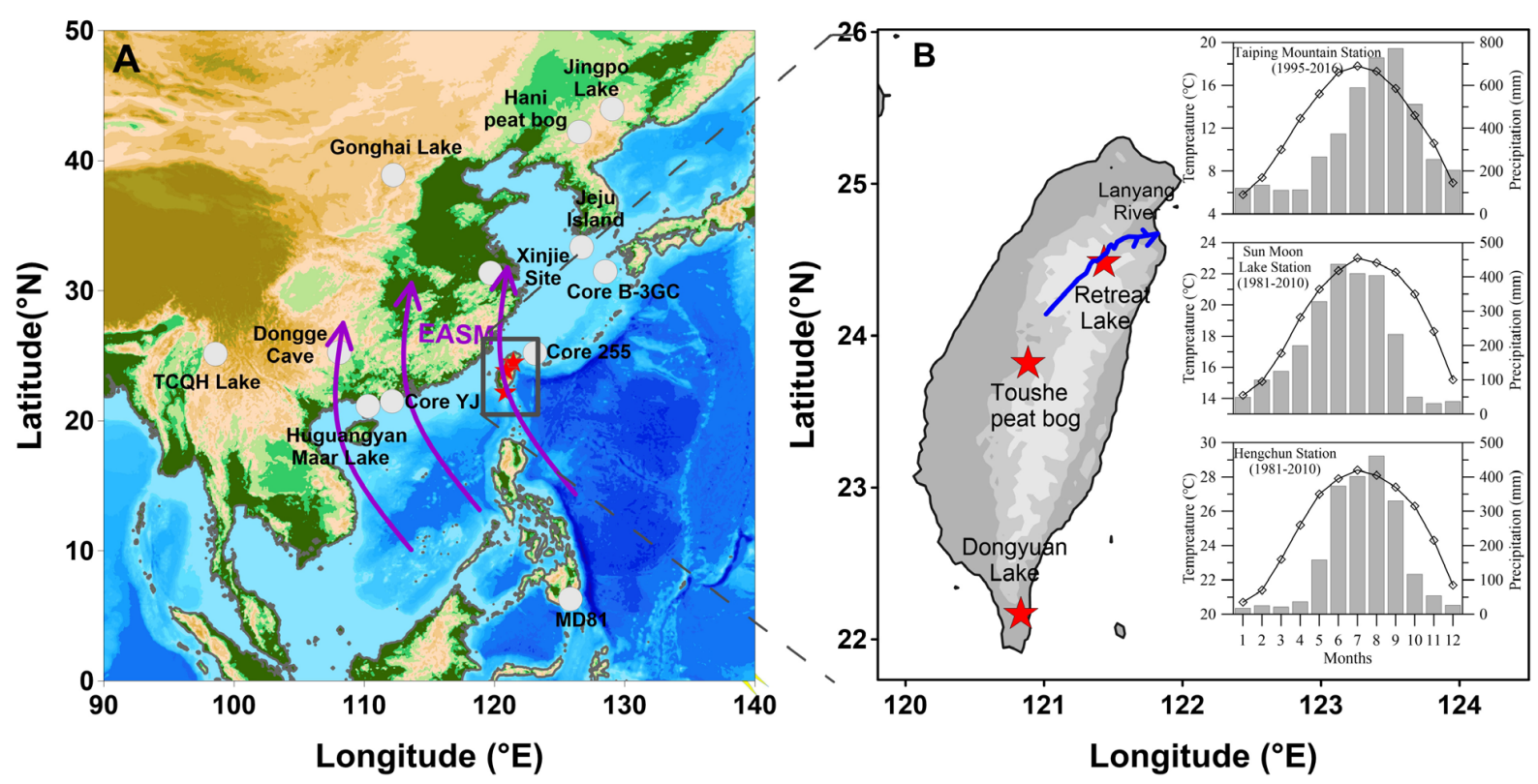

FIGURE 1 | (A) Locations of the climate records synthesized and discussed in this study. (B) Mean monthly temperature and precipitation in the meteorological stations near the three lakes and peat bog are provided (Taiping Mountain Station for Retreat Lake, Sun Moon Lake Station for Toushe peat bog and Hengchun Station for Dongyuan Lake). 
Retreat Lake is a shallow ( $<1.5 \mathrm{~m}$ depth) sub-alpine lake with a small surface area $\left(10^{4} \mathrm{~m}^{2}\right)$ located in northern Taiwan (Figure 1B). Because its hydrological system is closed, the lake level is mainly controlled by precipitation and evaporation. The lake is filled by monsoon-related precipitation during the summer and is almost dried out during the winter. The sediment deposited in the lake is entirely derived from the surrounding mountains and consists of argillite, slate, and phyllite. The lake levels were likely higher during the early stages according to the basin shape. Retreat Lake lies on the route of the EASM and close to the main axis of the northward flowing Kuroshio Current. According to the nearest weather station in Taiping Mountain, the mean monthly temperature is $12^{\circ} \mathrm{C}$ and ranges from $6^{\circ} \mathrm{C}$ in January to $18^{\circ} \mathrm{C}$ in July. The mean annual precipitation is $\sim 4000 \mathrm{~mm}$ and has strong seasonal variations (ranges from $110 \mathrm{~mm}$ in winter to $770 \mathrm{~mm}$ in summer), suggesting influences dominated by the summer monsoon. Modern vegetation in the drainage basin of Retreat Lake is composed of subtropical species, dominated by Cyclobalanopsis and Quercus (Selvaraj et al., 2011).

Toushe Peat Bog is located in central Taiwan (Figure 1B). The mean annual rainfall in this area is $2400 \mathrm{~mm}$, according to the nearest meteorological station, Sun Moon Lake. The mean monthly temperature is $19^{\circ} \mathrm{C}$ and ranges from 14 to $23^{\circ} \mathrm{C}$. Subtropical evergreen Lauro-Fagaceae forests currently occupy the Toushe Basin (Liew et al., 2006). A $40 \mathrm{~m}$ long sediment core was previously collected from this site, covering the last glacial period (Liew et al., 2006). The bog was a lake prior to the last glacial period but became a peat bog by the early stage of the glacial period and desiccated at $\sim 1.7 \mathrm{ka} \mathrm{BP}$ (Liew et al., 2006).

Dongyuan Lake is located on the eastern coast of southern Taiwan (Figure 1B), has a surface area of $2 \mathrm{~m} \times 10^{4} \mathrm{~m}$, and a catchment area of approximately $94 \mathrm{~m} \times 10^{4} \mathrm{~m}$. According to the Hengchun meteorological station near Dongyuan Lake, the mean monthly rainfall ranges from 20 to $460 \mathrm{~mm}$, with an annual rainfall of more than $2000 \mathrm{~mm}$. More than $90 \%$ of the annual rainfall occurs during the summer season. The mean monthly air temperature ranges from 21 to $28^{\circ} \mathrm{C}$, with a mean annual temperature of $25^{\circ} \mathrm{C}$. The lake has been undisturbed for the last $21 \mathrm{ka}$ and has become artificially managed in recent decades. The catchment of the lake is currently a swampy wetland dominated by species of Poaceae and Cyperaceae. The surrounding hills are covered by a subtropical evergreen forest (Lee and Liew, 2010).

The Lanyang River originates at Nan-Hu Mountain $(3535 \mathrm{~m}$ above sea level) with a mean $5 \%$ gradient. The length of the Lanyang River is $73 \mathrm{~km}$, with a drainage area of $980 \mathrm{~km}^{2}$. The average annual precipitation in the Lanyang watershed is approximately $3250 \mathrm{~mm}$, with rainfall being most abundant during the EASM season, particularly during typhoons. With a steep gradient and abundant rainfall, Lanyang River has one of highest sediment yields in the world, with a present-day annual sediment load of approximately 8-17 Mt/year (Jeng and Kao, 2002; Dadson et al., 2003; Milliman and Kao, 2005).

\section{PROXY VARIATIONS AND DISCUSSION}

\section{EASM Rainfall Variation in Taiwan During the Holocene}

In this synthesis, we compiled data from three individual lake and peat cores that span most of the Holocene period. The three cores were collected from the northern, central, and southern regions of Taiwan. We then compared these cores with the sedimentary history records derived from 12 on-land cores from northern Taiwan and landslide records based on accelerated mass spectrometer (AMS) ${ }^{14} \mathrm{C}$ from various locations in Taiwan (Table 1). For the sediment cores from the Toushe peat bog and Dongyuan Lake, we applied the interpretations presented in the original studies. The spore percentages (percentage of the sum of pollen and spores) in these two cores were used as an indicator of the moisture condition (Liew et al., 2006; Lee et al., 2010).

TABLE 1 | Paleoclimate records from Taiwan synthesized in this study.

\begin{tabular}{|c|c|c|c|c|c|c|c|c|}
\hline Site name & Location & Lake areas & Core length & Time span & $\begin{array}{l}\text { Dating } \\
\text { method }\end{array}$ & $\begin{array}{c}\text { Number of } \\
\text { dates }\end{array}$ & Proxies used & References \\
\hline Retreat Lake & $\begin{array}{l}\text { Northern Taiwan, } \\
24^{\circ} 29^{\prime} \mathrm{N}, 121^{\circ} 26^{\prime} \mathrm{E}\end{array}$ & $10^{4} \mathrm{~m}^{2}$ & $1.7 \mathrm{~m}$ & $10.3 \mathrm{ka}$ & ${ }^{14} \mathrm{C}$ & 10 & TOC & $\begin{array}{l}\text { Selvaraj et al., } \\
2007,2011\end{array}$ \\
\hline Toushe Basin & $\begin{array}{l}\text { Central Taiwan, } \\
23^{\circ} 49^{\prime} \mathrm{N} ; 120^{\circ} 53^{\prime} \mathrm{E}\end{array}$ & $1.75 \mathrm{~km}^{2}$ & $39.5 \mathrm{~m}$ & $96 \mathrm{ka}$ & ${ }^{14} \mathrm{C}$ & 13 & Spores & Liew et al., 2006 \\
\hline Dongyuan Lake & $\begin{array}{l}\text { Southern Taiwan, } \\
23^{\circ} 49^{\prime} \mathrm{N} ; 120^{\circ} 53^{\prime} \mathrm{E}\end{array}$ & $2 \times 10^{4} \mathrm{~m}^{2}$ & $15 \mathrm{~m}$ & $22 \mathrm{ka}$ & ${ }^{14} \mathrm{C}$ & 18 & Spores & Lee and Liew, 2010 \\
\hline Lanyang Plain & Northern Taiwan & & & & ${ }^{14} \mathrm{C}$ & $\begin{array}{c}116 \text { for } 12 \\
\text { cores }\end{array}$ & Sedimentation rate & Wu, 2013 \\
\hline Pa-chang River & $\begin{array}{l}\text { Southwestern } \\
\text { Taiwan }\end{array}$ & & & & ${ }^{14} \mathrm{C}$ & 55 & Number of ${ }^{14} \mathrm{C}$ dates & Hsieh et al., 2014 \\
\hline Hua-tung coast & Eastern Taiwan & & & & ${ }^{14} \mathrm{C}$ & 34 & Number of ${ }^{14} \mathrm{C}$ dates & Hsieh et al., 2011 \\
\hline $\begin{array}{l}\text { Trunk Cho-shui } \\
\text { River and } \\
\text { Chen-yeo-lan River }\end{array}$ & $\begin{array}{l}\text { Central-south } \\
\text { Taiwan }\end{array}$ & & & & ${ }^{14} \mathrm{C}$ & 25 & Number of ${ }^{14} \mathrm{C}$ dates & $\begin{array}{l}\text { Hsieh and Chyi, } \\
2010\end{array}$ \\
\hline Lao-nung River & $\begin{array}{l}\text { Central-south } \\
\text { Taiwan }\end{array}$ & & & & ${ }^{14} \mathrm{C}$ & 22 & Number of ${ }^{14} \mathrm{C}$ dates & $\begin{array}{l}\text { Hsieh and Chyi, } \\
2010\end{array}$ \\
\hline Nan-tzu-hsien River & $\begin{array}{l}\text { Southwestern } \\
\text { Taiwan }\end{array}$ & & & & ${ }^{14} \mathrm{C}$ & 7 & Number of ${ }^{14} \mathrm{C}$ dates & Hsieh et al., 2012 \\
\hline
\end{tabular}




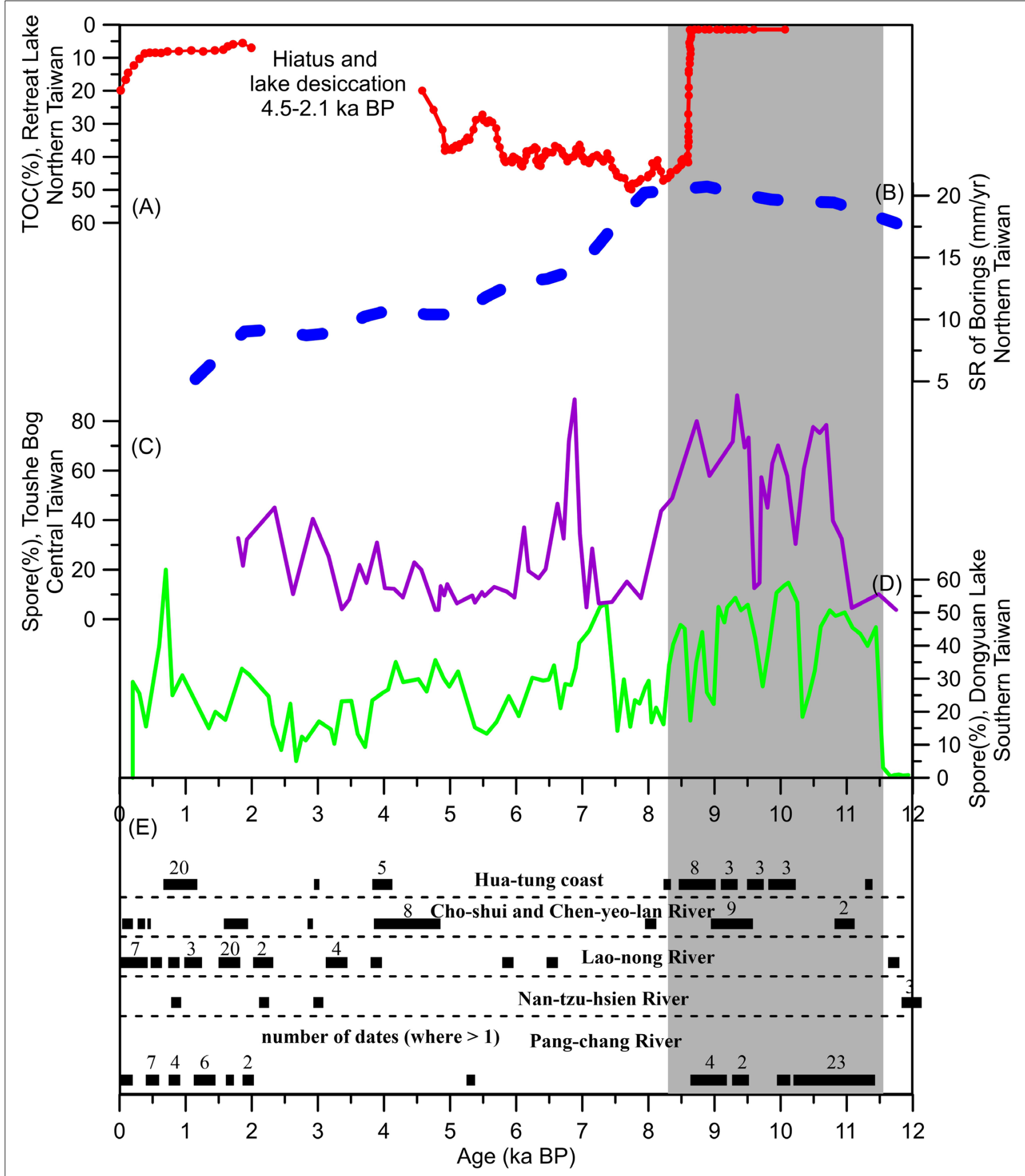

FIGURE 2 | Paleoclimate records from Taiwan. (A) TOC record from Retreat Lake (Selvaraj et al., 2011). (B) Variations in sedimentation rate from on-land cores in northern Taiwan (The blue dashed line, Wu, 2013). (C) Record of spore percentages from Toushe Basin (Liew et al., 2006). (D) Record of spore percentages from Dongyuan Lake (Lee and Liew, 2010). (E) Available radiocarbon dates derived from mass-wasting sequences compiled by Hsieh et al. (2014). Bars represent 1 $\sigma$ calibrated ranges or their combinations where more than one set of data are available. The numbers $(>1)$ of dates are shown above the bars. The gray bar highlights the EASM rainfall maximum during the early Holocene. 
However, the total organic carbon (TOC) content of the sediment core from Retreat Lake was used directly as an indicator of precipitation in the original studies (Selvaraj et al., 2007, 2011), which should be suspected. The extremely high TOC content during the middle Holocene was interpreted to represent a significantly increased summer monsoon rainfall (Selvaraj et al., 2007, 2011). However, the TOC proxy has been suggested to be sensitive to hydrological changes from peat conditions (high TOC) to a lacustrine status (low TOC) in southern China (Zhou et al., 2004). The much higher TOC content of the Retreat Lake during the middle Holocene might reflect a drier condition. This means that the water availability for Retreat Lake during the middle Holocene was low compared those during 10.3-8.6 ka BP and $2.1 \mathrm{ka} \mathrm{BP}$ to the present (Figure $2 \mathrm{~A}$ ). The $\mathrm{C} / \mathrm{N}$ ratios in the same core (Selvaraj et al., 2011) also point to a lake status during the early Holocene and the last 2 ka but a mire status during the middle Holocene.

Records from Taiwan through the Holocene are compiled in Figure 2. As mentioned above, the TOC proxy in Retreat Lake might reflect the changes of relatively dry swampy peat and wet lacustrine mud sequences. The lower TOC content from 10.3$8.6 \mathrm{ka}$ BP in Retreat Lake might suggest higher water availability due to wet conditions (Figure 2A). The percentages of Spores in the Toushe Basin and Dongyuan Lake exhibit sharp increases at around $11.5 \mathrm{ka} \mathrm{BP}$, indicating an intensification of the EASM after the Younger Dryas event. The percentages of spores in both lakes remained high until $\sim 8.2 \mathrm{ka} B P$, indicating high summer monsoon rainfall amounts during the early Holocene. Several centennial-scale oscillations punctuated this period (at 10.5, 9.7, and $9.2 \mathrm{ka} \mathrm{BP}$ ) (Figures 2C,D). Moreover, the mass-wasting records show that the largest mass-wasting activity in Taiwan occurred during the early Holocene (Figure 2E, 11.3-8.7 ka BP). These mass-wasting events collectively created extensive alluvial terraces (Hsieh et al., 2014). Although earthquakes can initiate mass-wasting, the synchronicity of the ages of the terraces constructed among different landforms prefer frequent heavy rain associated with the enhanced EASM rather than earthquakes for the genesis of these mass-wasting events (Hsieh et al., 2014). Moreover, the sediment record based on the 12 on-land cores from the Lanyang Plain in northern Taiwan suggests that particularly high accumulation rates occurred at 12-8 ka BP (Figure 2B), which were mainly induced by increased summer monsoon rainfall ( $\mathrm{Wu}, 2013)$. According to these observations, the records from Taiwan collectively show an early Holocene EASM rainfall maximum $(\sim 11.5-8 \mathrm{ka} \mathrm{BP})$.

The transition from lacustrine sediments to peat deposits are abrupt at $8.6 \mathrm{ka} \mathrm{BP}$ (drastic increase in TOC content) for Retreat Lake might reflect a decreased water availability due to drier conditions (Figure 2A). The sedimentation rate of on land cores from Lanyang Plain exhibit a decreasing trend since $8 \mathrm{ka} \mathrm{BP}$ (Figure 2B), which might attribute to a decreasing precipitation. Both of the spore records from central and southern Taiwan suggest a decreased EASM rainfall since $8 \mathrm{ka} \mathrm{BP}$, with a wet excursion at $\sim 7 \mathrm{ka} \mathrm{BP}$ (Figures 2C,D). Strikingly, the radiocarbon dates of the mass-wasting sequences also decreased since $8 \mathrm{ka} \mathrm{BP}$. The driest interval occurred at $\sim 4-$ $2 \mathrm{ka} \mathrm{BP}$, which is most pronounced in the records from Retreat
Lake and Dongyuan Lake. Retreat lake totally dried up during 4.5-2.1 ka BP as reflected by a hiatus during this interval, which is attributable to a collapse of the EASM at that time (Selvaraj et al., 2007, 2011). Although the spore record in the Toushe basin shows a slightly increasing trend since $3.3 \mathrm{ka}$ BP, the dry interval during 4-2 ka BP has been widely reported in many other records from Taiwan (Liew and Huang, 1994; Chen and $\mathrm{Wu}$, 1999; Wenske et al., 2011; Liew et al., 2014; Wang et al., 2015). Over the last two millennia, both the TOC record from Retreat Lake in northern Taiwan and the spore percentage record from Dongyuan Lake in southern Taiwan suggest an increased EASM rainfall (Figures 2A,C). Additionally, a significant increase in the number of radiocarbon dates of the mass-wasting sequences since 2 ka BP (Figure 2E) likely suggests that more landslide events occurred and were probably induced by frequent heavy rainfall. However, the sedimentation rate of on land cores from Lanyang Plain further decreased during last $2 \mathrm{ka}$ (Figure 2B), which may be ascribed to the strong influences of human activity.

Large uncertainties in the reconstructions of Holocene EASM rainfall in Taiwan may exist due to the small number of records available. Moreover, uncertainties might also be raised from the different proxies used as EASM rainfall indicators for different sites (i.e., TOC for northern Taiwan and spore percentages for central and southern Taiwan). The different proxies used as precipitation indicators could be complicated by additional factors such as sampling resolution, local surface processes, and climatic sensitivity to the large-scale climatic forcing factors for each individual proxy. For example, the wet excursion at $\sim 7 \mathrm{ka}$ BP registered in pollen records from central and southern Taiwan is not detected in TOC records from northern Taiwan. This discrepancy might be caused by the climatic sensitivity of different proxies. Despite the large uncertainties in their details, the general consistency in temporal patterns among different records indicate that these records can be used for regional comparisons.

\section{Early Holocene EASM Rainfall Maximum in Taiwan and Spatiotemporal Pattern of the Holocene EASM Rainfall Maximum Across China}

A detailed comparison of EASM proxies from Taiwan with other regional paleoclimate records is shown in Figure 3. The temporal pattern of the EASM rainfall during the Holocene, registered in archives from Taiwan, appears to vary in agreement with other monsoon rainfall records from southern China, collectively suggesting an early Holocene EASM rainfall maximum and a relatively drier middle to late Holocene (Figure 3). Well-dated high-resolution pollen records from Huguangyan Maar Lake clearly show an early Holocene EASM maximum (11.5-8 ka BP) and a relatively dry middle to late Holocene (Figure 3E; Wang et al., 2016; Sheng et al., 2017). Small grain-size fractions from Tengchongqinghai Lake in southwestern China, which have been interpreted as an indicator of monsoon precipitation (Zhang et al., 2017), also show similar trends than the records from Taiwan throughout the Holocene, with an early Holocene rainfall maximum (Figure 3F). It is worth noting that the general trend of 


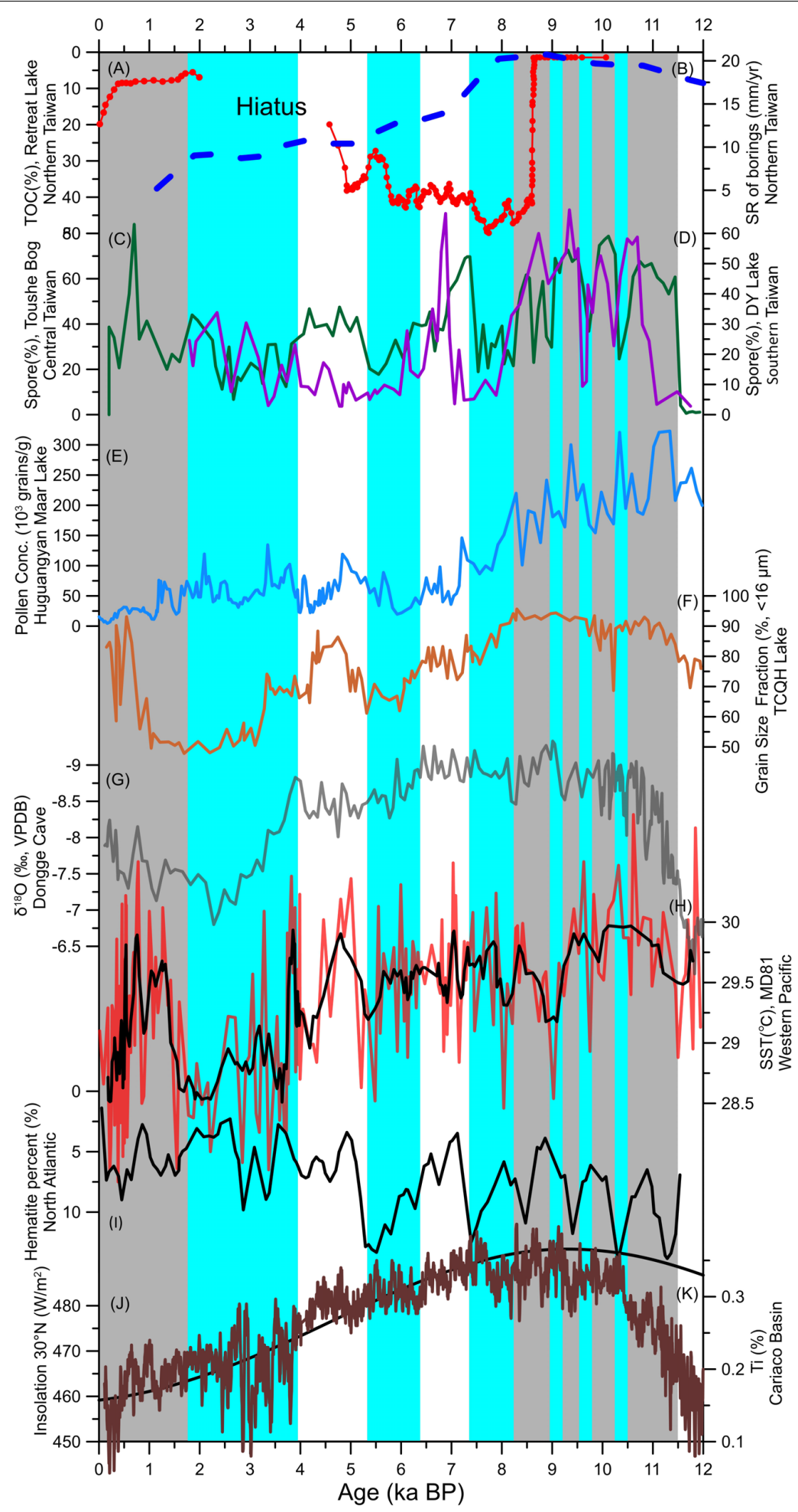

FIGURE 3 | Comparisons of paleoclimate records from Taiwan (A-D) with regional and global climatic records (E-K). (A) TOC record from Retreat Lake (Selvaraj et al., 2011). (B) Variations in sedimentation rate from on-land cores in northern Taiwan (The blue dashed line, Wu, 2013). (C) Record of spore percentage from Toushe Basin (The purple line, Liew et al., 2006). (D) Record of spore percentage from Dongyuan Lake (The green line, Lee and Liew, 2010). (E) Variations in pollen concentrations from Huguangyan Maar Lake (Wang et al., 2016). (F) Small grain size contents from Tengchongqinghai Lake. (G) Speleothem $\delta^{18} \mathrm{O}$ records from Dongge (Dykoski et al., 2005). (H) SST records from the MD81 site in the western tropical Pacific (Stott et al., 2004). (I) Hematite percentages in the North Atlantic (Bond et al., 2001). (J) Summer insolation at 30 N (The black line, Berger and Loutre, 1991). (K) Ti records from the Cariaco Basin, off the coast of Venezuela (The brown line, Haug et al., 2001). The gray bars highlight the early Holocene rainfall maximum and the "2-ka shift." The cyan bars indicate dry events. 
EASM rainfall was punctuated by a series of centennial-timescale dry events (10.5, 9.7, and 9.2 ka BP) that have also been identified in various paleoclimatic records from southern China (Wang et al., 2016; Yang et al., 2019; Xu et al., 2020). These events coincide with low sea surface temperature (SST) events in the Western Pacific Warm Pool (WPWP; Figure 3H; Stott et al., 2004) and may correspond to North Atlantic ice-rafting events (Figure 3I; Bond, 1997; Bond et al., 2001). The in-phase pattern and consistencies in timing of these oscillations may suggest a strong teleconnection between the climate systems in low latitude and northern high latitude regions.

It has previously been assumed that precession-induced changes in the Northern Hemisphere summer insolation (NHSI) modulated EASM rainfall variations on an orbital timescale during the Holocene (Wang et al., 2001, 2017; Cheng et al., 2016; Lu et al., 2019; Yang et al., 2019; Zhang et al., 2019). The monsoon rainfall records from Taiwan and other records from southern China do track changes in the NHSI, showing an increased summer rainfall during the early Holocene and decreased summer rainfall during the middle to late Holocene (Figure 3). Asynchronous responses of surface temperatures over the land and ocean to insolation heating generate enhanced landocean thermal gradients and increased onshore moist air flow in the summer during precession maxima, resulting in increased EASM rainfall during the early Holocene. Furthermore, elevated NHSI during the early Holocene (Figure $3 \mathbf{J}$ ) may have induced higher SSTs in the WPWP (Figure 3F; Stott et al., 2004), causing an elevated seawater evaporation rate and a northward migration of the mean annual location of the Intertropical Convergence Zone (ITCZ; Figure 3K). This would have enhanced monsoon circulation and brought a large amount of evaporated water vapor from tropical and subtropical oceanic regions to the East Asian continent, which in turn caused more summer rainfall in subtropical monsoonal East Asia (Stott et al., 2004; Sun and Feng, 2013; Li et al., 2018; Lu et al., 2019). However, the changes in the NHSI and SSTs of the WPWP cannot explain all of the observed EASM rainfall variability during the Holocene or the existence of the spatiotemporal heterogeneity of EASM rainfall in China (Chen F. et al., 2015; Lu et al., 2019; Xu et al., 2020).

As mentioned above, the monsoon rainfall records from southern China collectively show an early Holocene rainfall maximum at $\sim 11.5-8 \mathrm{ka} B$. However, quantitative reconstructions of annual and summer rainfall amounts, based on high-resolution pollen records from the Xinjie site on the lower reaches of the Yangtze River, indicate that the maximum summer rainfall occurred between $\sim 10-6$ ka BP (Figure 4; Lu et al., 2019), which is slightly later than records from southern China. Li et al. (2018) reported a similar pattern (EASM rainfall maximum at $\sim 10-7 \mathrm{ka} \mathrm{BP}$ ) based on three high-resolution fossil pollen sequences from the lower Yangtze region $\sim 220 \mathrm{~km}$ west of the Xinjie site. Moreover, paleoclimate records from arid/semi-arid northern China exhibit a very different pattern, indicating a middle Holocene EASM rainfall maximum (Lu et al., 2013; Wang and Feng, 2013; Li et al., 2014; Wang H. et al., 2014; Chen F. et al., 2015; Guo et al., 2018). For example, a quantitative reconstruction of Holocene EASM rainfall, based on a well-dated high-resolution pollen record from

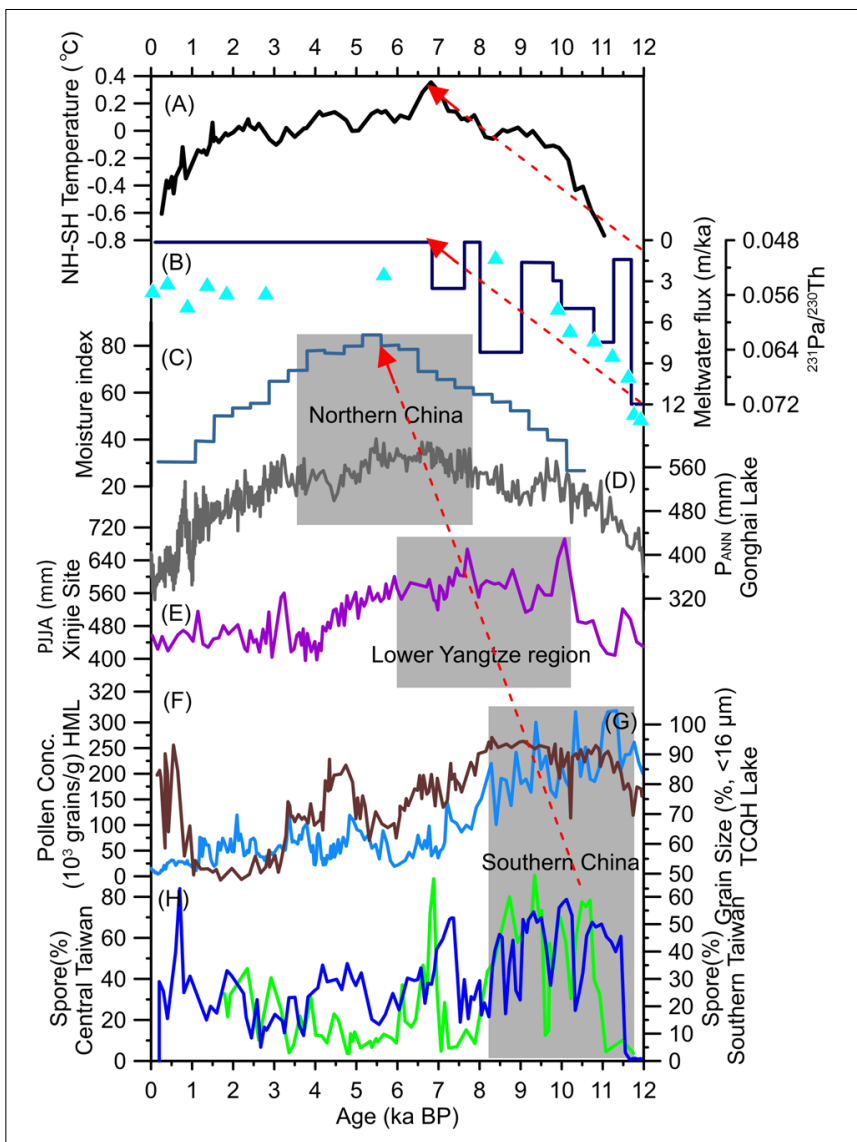

FIGURE 4 | Comparisons of the summer monsoon rainfall maximum across China. (A) North-South hemisphere temperature gradients (McGee et al., 2014). (B) Meltwater flux in the Northern Hemisphere in TRACE21 (dark blue line, Liu et al., 2014a) and ${ }^{231} \mathrm{~Pa} /{ }^{230}$ Th ratio in Western subtropical Atlantic (cyan triangles), a proxy for the AMOC (McManus et al., 2004).

(C) Synthesized moisture index for arid/semiarid northern China (Li et al., 2014). (D) Annual rainfall from Gonghai Lake, northern China (Chen F. et al., 2015). (E) Summer rainfall reconstructions for the Xinjie site in the lower Yangtze region (Lu et al., 2019). (F) Variations in pollen concentrations from Huguangyan Maar Lake (The blue line, Wang et al., 2016). (G) Small grain size contents from Tengchongqinghai Lake (The brown line, Zhang et al., 2017). (H) Records of spore percentages from Toushe Basin (The green line, Liew et al., 2006) and from Dongyuan Lake (The dark blue line, Lee and Liew, 2010). The gray bars highlight the EASM rainfall maximum.

an alpine lake in northern China, indicates that the rainfall maximum occurred during the middle Holocene (Figure 4; Chen F. et al., 2015). A reconstruction of effective moisture levels, based on analyses of changes in sedimentary facies of aeolian deposits and vegetation types in the desert regions of northern China, indicates that the effective moisture reached a peak from 8-4 ka BP (Figure 4; Li et al., 2014). A pollen-based moisture index, synthesized from six Holocene sequences from the summer monsoon-influenced semi-arid belt, also indicates that a pronounced middle Holocene EASM rainfall maximum occurred at $\sim 8.5-4.5 \mathrm{ka} \mathrm{BP}$ (Wang and Feng, 2013).

To investigate the spatial patterns of the Holocene EASM rainfall maximum across China, we compared the rainfall records 
from southern China with those from the lower Yangtze region and northern China (Figure 4). We found apparent timetransgressive onsets and terminations of the Holocene rainfall maximum between 11.5 and $8 \mathrm{ka}$ BP in southern China, 10$6 \mathrm{ka} \mathrm{BP}$ for the lower reaches of the Yangtze region, and 8$4 \mathrm{ka}$ BP for northern China. Increasing evidence and model results suggest that additional forcing mechanisms may also modulate the EASM rainfall patterns, such as westerlies and Western Pacific subtropical high (WPSH; Chiang et al., 2015; Kong et al., 2017; Zhang et al., 2018; Xu et al., 2020). Unlike the tropical Indian summer monsoon, the EASM has more complex moisture sources and rainfall structures and is closely associated with low-level southwesterly airflow and the migration of the rain belt-known as the mei-yu (in Korean: changma, and in Japanese: baiu) front in China (Ding and Chan, 2005; Wang et al., 2008). The summer rainfall varies significantly from southern to northern China because of the seasonal migration of the mei-yu front/WPSH. It should be noted that the mei-yu rain belt lies on the northwestern flank of the WPSH. Recently, $\mathrm{Xu}$ et al. (2020) argued that the intensity and location of the WPSH, which are induced by inter-hemispheric and/or zonal Pacific temperature gradients, modulated the summer monsoon rainfall in subtropical China during the Holocene. In addition, the north-south displacement of the westerlies has also been proposed to be responsible for the Holocene EASM rainfall variability (Chiang et al., 2015; Sun et al., 2015; Kong et al., 2017). Based on comparisons of model results with proxy data, Sun et al. (2015) note that insolation forcing has a greater impact on the precipitation change in southern than in northern China, whereas the glacial forcing has a weaker impact in southern China compared to northern China. They argued that the different summer precipitation responses to solar insolation and glacial forcing between northern China and southern China reflect the complex dynamics of the EASM, linked to high- and lowlatitude climates through migrations of westerlies and WPSH (Sun et al., 2015). Here, we propose that the time-transgressive EASM rainfall maximum from southern to northern China might be induced by the migration of the meridional location of the westerlies and WPSH, which may have been modulated by interhemispheric temperature gradients.

Inter-hemispheric temperature gradients $\left(\Delta \mathrm{T}_{\mathrm{N}-\mathrm{S}}\right)$ are important for modulating the meridional location of the planetary atmospheric circulation systems (Toggweiler, 2009; McGee et al., 2014; Xu et al., 2019). For example, increased $\Delta \mathrm{T}_{\mathrm{N}-\mathrm{S}}$ can be expected to push the northern hemisphere westerlies and the ITCZ northward and vice versa (McGee et al., 2014; Putnam and Broecker, 2017). The NPSH is also expected to move synchronously. From modern observations, the WPSH shifts to its northernmost location at August, when the SSTs are highest in the northern Hemisphere and lowest in the southern Hemisphere. It is reasonable to expect a northward shift of the NPSH with an increasing $\Delta \mathrm{T}_{\mathrm{N}-\mathrm{S}}$. Thus, changes in $\Delta \mathrm{T}_{\mathrm{N}-\mathrm{S}}$ could potentially change the meridional location of the westerlies and WPSH and consequently modulate the rain belt migration in China, especially on long timescales. As shown in Figure 4A, $\Delta \mathrm{T}_{\mathrm{N}-\mathrm{S}}$ was relatively lower during the early Holocene compared to the middle Holocene. The location of the westerlies and WPSH might have been sustained at a more southern location, leading to increased monsoon precipitation in southern China and a short rainy season in northern China during the early Holocene (Figure 4). With gradual increases in $\Delta \mathrm{T}_{\mathrm{N}-\mathrm{S}}$, the westerlies and WPSH might have shifted further north, leading to the onset of the monsoon rainfall maximum in the lower Yangtze region at $\sim 10 \mathrm{ka}$ BP (Figure 4). Eventually, the westerlies and WPSH reached its northernmost location at $\sim 7 \mathrm{ka} B P$ when the Holocene monsoon rainfall peaked in northern China (Figure 4). Moreover, the ice volume in the northern high latitudes was still large during the early Holocene. The melting freshwater from the Laurentide ice sheet was continuously delivered to the North Atlantic until $\sim 7$ ka (Figure 4B; Carlson et al., 2008; Liu et al., 2014a). The discharge of meltwater into the North Atlantic can slow down the Atlantic meridional overturning circulation (AMOC), which can change the inter-hemispheric thermal gradient (Toggweiler, 2009; McGee et al., 2014) and shift the mean position of the westerlies and perhaps the WPSH. The more southern position of the westerlies and WPSH during the early Holocene may be responsible for the drier climate in northern China. As shown in Figure 4B, with the gradually diminished meltwater flux and the recovered AMOC during the early Holocene, the westerlies and WPSH might also shift northward gradually. The northward shift of the WPSH is generally accompanied by a stronger southerly wind over eastern China, which increases the monsoon rainfall in northern China (Liu et al., 2014b). Paleoclimate Modeling Intercomparison Project (PMIP) models also simulated a stronger EASM than baseline EASM during the middle Holocene (Jiang et al., 2013).

Similar to our observations, a time-transgressive termination of the African Humid Period during the Holocene has been reported and was attributed to decreasing summer insolation and the gradual southward migration of the tropical rain belt (Shanahan et al., 2015). An et al. (2000) reported a time-transgressive EASM rainfall maximum from northwest to southeast China throughout the Holocene, which was attributed to the southeastward shift of the monsoon front and weakening summer insolation. However, due to the poor chronological controls and low sampling resolution, the timing of the EASM rainfall maximum is not well constrained. Subsequent evidence from the last 20 years also does not support a southward shift of the maximum precipitation belt. Recently, Zhou et al. (2016) suggested the opposite pattern, based on tree pollen records across China, with a marked northward migration of the onset of the "Holocene optimum" in East Asia, from $\sim 10 \mathrm{ka}$ BP in southern China to $\sim 6 \mathrm{ka}$ BP in northeastern China. However, the "Holocene Optimum" in their study depended on the thermal or moisture condition in different regions, which may not solely reflect the summer monsoon rainfall maximum (Zhou et al., 2016). In this study, we focused on the rainfall maximum without considering the temperature. As shown in Figure 4, well-dated and quantitative reconstructions of EASM rainfall records (from the Gonghai Lake and Xinjie site) were selected as the representative records for northern China and the lower reaches of the Yangtze region. Although palynological records from Taiwan are not quantitative reconstructions, like those from the Gonghai Lake and Xinjie site, similar temporal patterns 
between spore percentages, sedimentary history records, and mass-wasting records across Taiwan (which are independent with temperature condition) suggest that the spore percentages can faithfully reflect the EASM rainfall variations in Taiwan. Moreover, pollen analyses of the same records based on a biomization technique (Liew et al., 2006; Lee et al., 2010) pointed out that the Holocene Thermal Optimum in Taiwan occurred at $\sim 8-4 \mathrm{BP}$ which is different from the early Holocene rainfall maximum indicated by spore percentages. Additional quantitative reconstructions of summer precipitation, especially in southern China, are needed in the future to illustrate the spatial and temporal variabilities of EASM precipitation during the Holocene.

\section{Drought in Taiwan During 4-2 ka BP and a Possible Link to El Niño-Southern Oscillation}

During the late Holocene, the EASM rainfall exhibits a more complex pattern. A catastrophic drought occurred in Taiwan from 4 to $2 \mathrm{ka} \mathrm{BP}$, followed by an increase in EASM rainfall during the last $2 \mathrm{ka}$. The dry interval at 4-2 ka BP has also been reported in other records from Taiwan (Liew and Huang, 1994; Chen and Wu, 1999; Wenske et al., 2011; Wang et al., 2015). In addition, this dry interval has been broadly reported in records from coastal East Asia and/or subtropical East Asia (Figure 4). Chen R. et al., 2015 reported a dry interval between $\sim 3.6$ and $2.1 \mathrm{ka}$ BP based on a sediment record retrieved from Jingpo Lake in northeastern China (Figure 5A). Similar results have also been obtained from a peat core from the Haini Peat in northeastern China (Figure 5B; Hong et al., 2005). Multi-proxy evidence obtained from a sediment core retrieved from the Mulyoungari crater swamp on Jeju Island, South Korea, also suggests a dry interval between 4.3 and 1.9 ka BP (Figure 5C; Park et al., 2016). Near cessation of peat deposition and negligible sedimentation between 4 and $2 \mathrm{ka} \mathrm{BP}$ in the Kimotsuki lowland delta plain of Southern Japan, suggests greatly reduced precipitation (Ishii, 2018). Multi-proxy evidence from a marine sediment core from the inner shelf of the northern South China Sea also suggests reduced summer rainfall at 3.5-2 ka BP (Figure 5E; Huang C. et al., 2018). The grain size fraction in Tengchongqinghai Lake (Zhang et al., 2017) and the redness values in Qinghai Lake (Ji et al., 2005) also suggest decreased summer monsoon rainfall. Moreover, the dry interval from 4 to $2 \mathrm{ka} \mathrm{BP}$ can also be identified in stalagmite $\delta^{18} \mathrm{O}$ records, such as those from Dongge Cave (Figure 3H; Dykoski et al., 2005) in southern China, Jiuxian Cave in central China (Cai et al., 2010), Tianmen Cave on the southern Tibetan Plateau (Cai et al., 2012), and Qunf Cave in southern Oman (Fleitmann, 2003).

Since the water vapor supply for the EASM region is mainly derived from the WPWP (Ding and Chan, 2005; Liu et al., 2014b), variations in SST in the WPWP are likely to influence the water vapor availability and hence summer precipitation in East Asia. Furthermore, increased El Niño-Southern Oscillation (ENSO) activity since the late Holocene might also have a significant impact on the EASM rainfall (Conroy et al., 2008; Cai et al., 2010; Selvaraj et al., 2011; Park et al., 2016; Xu et al., 2016;
Huang C. et al., 2018). The catastrophic droughts at 4-2 ka may have coincided with decreased SSTs in the WPWP and increased ENSO activity (Figures 5H,I). It has been reported that the frequency and intensity of ENSO significantly increased since $\sim 4$ ka BP (Figure 5I; Rein, 2007; Conroy et al., 2008). Reconstructions suggest that El Niño events occurring at 4$2 \mathrm{ka}$ BP were among the strongest in the Holocene (Rein, 2007). Cores from coral reef frameworks along an upwelling gradient in the tropical eastern Pacific show that reef ecosystems in the tropical eastern Pacific collapsed between 4 and $1.5 \mathrm{ka} \mathrm{BP}$, which coincided with greatly increased El Niño events (Toth et al., 2012). It is likely that El Niño-like conditions persisted during 42 ka BP. During El Niño-like conditions, a decline in the SST of the WPWP due to the amount of warm water mass brought to the eastern tropical Pacific, may have induced less formation of water vapor over the WPWP and thus less moisture was available for the subtropical East Asian monsoon region (Chen R. et al., 2015; Park et al., 2016; Huang C. et al., 2018; Li et al., 2018). In addition, a significantly southward shift of the ITCZ with high variabilities at 4-2 ka BP (Figure 3K) might also have contributed to decreased EASM rainfall. Moreover, a corresponding attenuation of warm Kuroshio currents at 4-2 ka BP (as indicated by a decrease in the abundance of foraminifera Pulleniatina obliquiloculata in sediment cores from the Okinawa Trough, Figure 5D) might also have significantly decreased the summer monsoon rainfall in Taiwan and northeastern Asia (Figure 5; Selvaraj et al., 2007; Park et al., 2016).

\section{The 2-ka Shift}

For the past $2 \mathrm{ka}$, it seems the EASM rainfall has increased according to the records from Taiwan. Proxies from both northern and southern Taiwan suggest increased summer precipitation. Moreover, mass-wasting records also indicate that landslide events have increased significantly during last $2 \mathrm{ka}$. A strengthening of the Asian summer monsoon for the last $2 \mathrm{ka}$ was identified in numerous paleoclimatic records from monsoonal regions in Asia and seems to be a robust feature (Zhao et al., 2013). Most of these monsoon rainfall records in their synthesis are from subtropical East Asia (see in Zhao et al., 2013). Recently, Cheng et al. (2016) noted that the Asian summer monsoon registered in stalagmite records deviated from the downward trend in NHSI through the Holocene over the last $2 \mathrm{ka}$. They termed this late Holocene anomaly as the "2-ka shift." They also suggested that this "shift" anti-correlated with monsoon records from South America and some temperature records from Antarctica, a scenario very similar to the millennialscale events throughout the past glacial-interglacial cycles, which is mainly caused by changes in the intensity of the AMOC. Cheng et al. (2016) suggested that a possible increase in the intensity of the AMOC may explain the "2-ka shift." Moreover, progressive increases in the concentrations of greenhouse gases have been proposed as being responsible for the intensification of the Asian monsoon since 2 ka BP (Zhao et al., 2013; Lu et al., 2019). However, records from northern China show a persistently decreasing trend during the late Holocene (Figure 4; Li et al., 2014; Chen F. et al., 2015) which likely contradicts with the increased intensity of the AMOC and greenhouse gas 


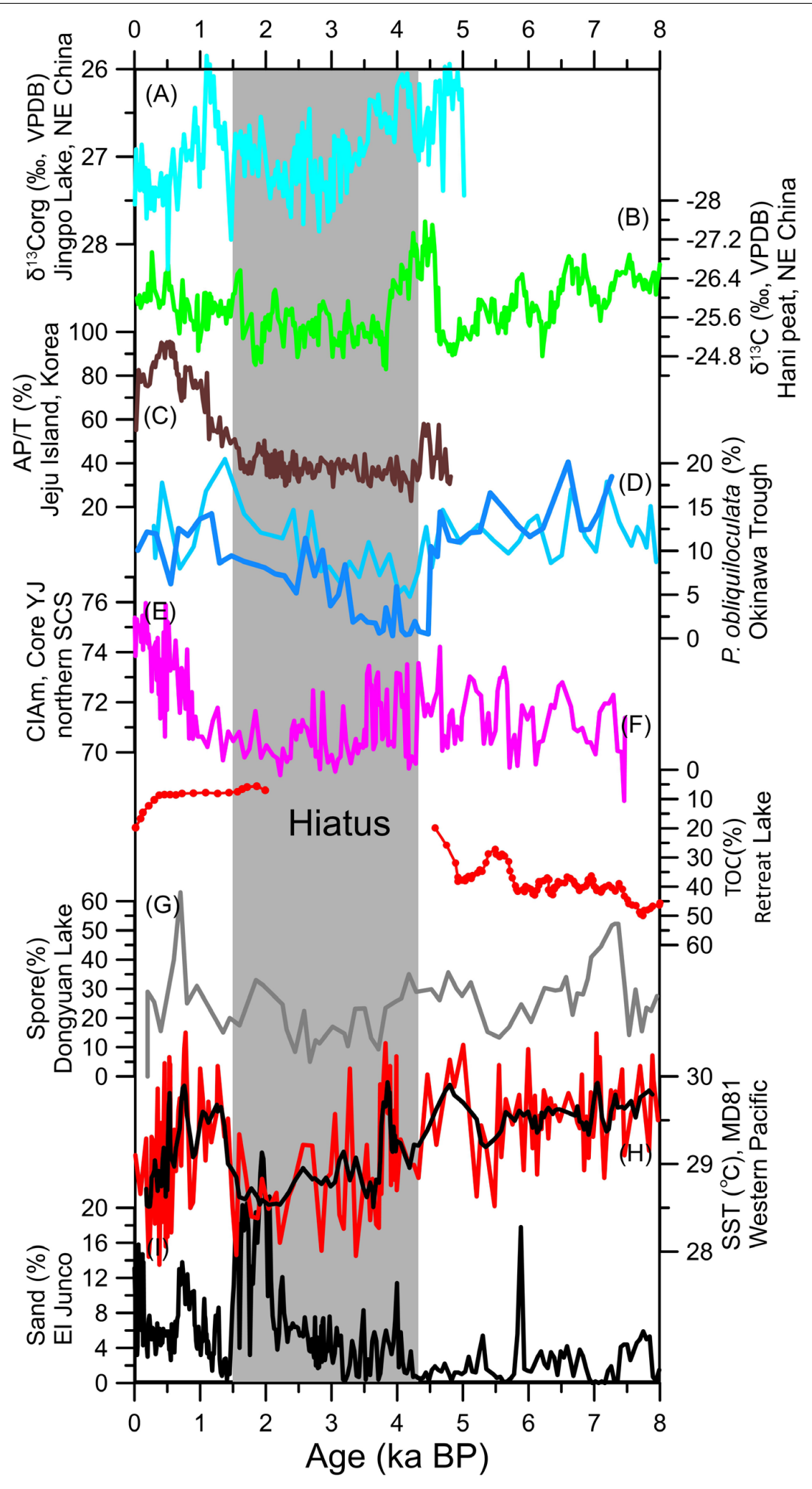

FIGURE 5 | Records showing the prolonged dry interval from 4 to 2 ka BP. (A) $\delta^{13}$ Corg values from Jingpo Lake, northeastern China (Chen R. et al., 2015). (B) Cellulose $\delta^{13} \mathrm{C}$ record from Hani peat (Hong et al., 2005). (C) Arboreal pollen/total pollen (AP/T) ratios from Jeju Island, South Korea (Park et al., 2016). (D) Abundances of the foraminifera Pulleniatina obliquiloculata from the Okinawa Trough (Jian et al., 2000). (E) Records of chemical weathering proxies (CIAm) from the northern inner shelf of the South China Sea (Huang C. et al., 2018). (F) TOC record from Retreat Lake (Selvaraj et al., 2007). (G) Record of spore percentages from Dongyuan Lake (Lee and Liew, 2010). (H) SST records from the MD81 site in the western tropical Pacific (Stott et al., 2004). (I) Sand percentages from El Junco Lake, eastern tropical Pacific (Conroy et al., 2008). 
forcing. We propose that the "2-ka shift" might also, or at least partly, be induced by a southward shift of the WPSH, associated with a gradual decrease in $\Delta \mathrm{T}_{\mathrm{N}-\mathrm{S}}$ during the late Holocene (Figure 4). This proposal is supported by the opposing trends of EASM rainfall between northern and southern China during the last $2 \mathrm{ka}$.

\section{CONCLUSION}

In this study, we integrate the lake and peat records that cover the entire Holocene epoch with mass-wasting records and depositional history records from Taiwan, to illustrate the variations in EASM rainfall in Taiwan throughout the Holocene. Records from Taiwan indicate an early Holocene EASM rainfall maximum and agree with other EASM records from southern China. We suggest that the early Holocene EASM rainfall maximum in southern China was mainly forced by a higher NHSI and elevated SSTs in the WPWP. In addition, we observed the transgressive timing of the EASM rainfall maximum across China, which may be due to the latitudinal shift of the westerlies and WPSH that were induced by a gradually increasing $\Delta \mathrm{T}_{\mathrm{N}-\mathrm{S}}$ and diminishing ice volume during the early to middle Holocene. Combined with other records from the East Asian monsoon region and the tropical Pacific, we found a pronounced dry interval at 4-2 ka BP, which probably resulted from prevailing El Nino-like conditions and drastically decreased SSTs in the WPWP during this interval. For the last $2 \mathrm{ka}$, the EASM has increased abnormally as compared to the downward trend of the NHSI. Besides the changes in the intensity of AMOC and/or increased concentrations of greenhouse gases during the last $2 \mathrm{ka}$, a southward shifting WPSH, associated with a gradual decrease $\Delta \mathrm{T}_{\mathrm{N}-\mathrm{S}}$ during the late Holocene, might have contributed to the EASM rainfall anomaly in southern China. The meridional SST gradients are expected to increase as global warming continues (Rind, 1998), which might cause a northward shift of the WPSH (analogous to the conditions during the middle Holocene), leading to an increased EASM rainfall in northern China and a decreased EASM rainfall in southern China. Our discussions on the spatiotemporal variability of the Holocene EASM rainfall, which are helpful for understanding the potential forcing mechanisms for EASM variations and predicting future hydroclimate changes in East

\section{REFERENCES}

An, Z., Liu, T., Lu, Y., Porter, S. C., Kukla, G., Wu, X., et al. (1990). The long-term paleomonsoon variation recorded by the loess-paleosol sequence in Central China. Quat. Int. 7, 91-95. doi: 10.1016/1040-6182(9)90042-3

An, Z., Porter, S., Kutzbach, J., Wu, X., Wang, S., Liu, X., et al. (2000). Asynchronous Holocene optimum of the East Asian monsoon. Quat. Sci. Rev. 19, 743-762. doi: 10.1016/S0277-3791(99)00031-1

An, Z., Wu, G., Li, J., Sun, Y., Liu, Y., Zhou, W., et al. (2015). Global monsoon dynamics and climate change. Annu. Rev. Earth Planet. Sci. 43, 29-77. doi: 10.1146/annurev-earth-060313-054623

Baker, A. J., Sodemann, H., Baldini, J. U. L., Breitenbach, S. F. M., Johnson, K. R., van Hunen, J., et al. (2015). Seasonality of westerly moisture transport in the East Asian summer monsoon and its implications for interpreting precipitation 818O. J. Geophys. Res-Atmos. 120, 5850-5862. doi: 10.1002/2014jd022919
Asia under the scenario of global warming. However, welldated high-resolution records of Holocene EASM rainfall in subtropical East Asia are still sparse. Additional high-resolution and quantitative reconstructions of EASM rainfall in low latitude regions are warranted to illustrate the detailed information of the spatiotemporal variabilities in the EASM precipitation during the Holocene. More simulation works with high resolution are also needed in the future to investigate the possible forcing mechanisms on the spatiotemporal heterogeneity of EASM rainfall during the Holocene.

\section{DATA AVAILABILITY STATEMENT}

The raw data supporting the conclusions of this article will be made available by the authors, without undue reservation, to any qualified researcher.

\section{AUTHOR CONTRIBUTIONS}

$\mathrm{XD}$ conceived the research idea and wrote the manuscript with contributions from all authors. LZ discussed and conducted the figure drafting for this manuscript. XZ and S-JK carried out a lot of the paleoenvironmental explanations and improved the manuscript. All authors contributed to the article and approved the submitted version.

\section{FUNDING}

This research was funded by the school-level general research project of North Minzu University (2020XYZSK03), the Doctoral Scientific Research Foundation of the North Minzu University, and the National Natural Science Foundation of China (NSFC 41806062).

\section{ACKNOWLEDGMENTS}

We acknowledge the editor $\mathrm{HX}$ and the reviewers for their insightful comments and constructive suggestions which significantly improved this manuscript.

Beck, J. W., Zhou, W., Li, C., Wu, Z., White, L., Xian, F., et al. (2018). A 550,000year record of East Asian monsoon rainfall from $10 \mathrm{Be}$ in loess. Science 360, 877-881. doi: 10.1126/science.aam5825

Berger, A., and Loutre, M. F. (1991). Insolation values for the climate of the last 10 million years. Quat. Sci. Rev. 10, 297-317. doi: 10.1016/0277-3791(91)90033-q

Bond, G. (1997). A pervasive millennial-scale cycle in north atlantic holocene and glacial climates. Science 278, 1257-1266. doi: 10.1126/science.278.5341. 1257

Bond, G., Kromer, B., Beer, J., Muscheler, R., Evans, M. N., Showers, W., et al. (2001). Persistent solar influence on North Atlantic climate during the Holocene. Science 294, 2130-2136. doi: 10.1126/science.1065680

Cai, Y., Tan, L., Cheng, H., An, Z., Edwards, R. L., Kelly, M. J., et al. (2010). The variation of summer monsoon precipitation in central China since the last deglaciation. Earth Planet. Sci. Lett. 291, 21-31. doi: 10.1016/j.epsl.2009. 12.039 
Cai, Y., Zhang, H., Cheng, H., An, Z., Edwards, R. L., Wang, X., et al. (2012). The Holocene Indian monsoon variability over the southern Tibetan Plateau and its teleconnections. Earth Planet. Sci. Lett. 335, 135-144. doi: 10.1016/j.epsl.2012. 04.035

Caley, T., Roche, D. M., and Renssen, H. (2014). Orbital Asian summer monsoon dynamics revealed using an isotope-enabled global climate model. Nat. Commun. 5:5371. doi: 10.1038/ncomms6371

Carlson, A. E., LeGrande, A. N., Oppo, D. W., Came, R. E., Schmidt, G. A., Anslow, F. S., et al. (2008). Rapid early Holocene deglaciation of the Laurentide ice sheet. Nat. Geosci. 1, 620-624. doi: 10.1038/ngeo285

Chen, C.-S., and Chen, Y.-L. (2003). The rainfall characteristics of Taiwan. Mon. Weather Rev. 131, 1323-1341. doi: 10.1175/1520-04932003131(1323:TRCOT(2. $0 . \mathrm{CO} ; 2$

Chen, F., Xu, Q., Chen, J., Birks, H. J. B., Liu, J., Zhang, S., et al. (2015). East Asian summer monsoon precipitation variability since the last deglaciation. Sci. Rep. 5:11186. doi: $10.1038 /$ srep 11186

Chen, R., Shen, J., Li, C., Zhang, E., Sun, W., and Ji, M. (2015). Mid-to lateHolocene East Asian summer monsoon variability recorded in lacustrine sediments from Jingpo Lake, Northeastern China. Holocene 25, 454-468. doi: $10.1177 / 0959683614561888$

Chen, J., Rao, Z., Liu, J., Huang, W., Feng, S., Dong, G., et al. (2016). On the timing of the East Asian summer monsoon maximum during the Holocene-Does the speleothem oxygen isotope record reflect monsoon rainfall variability? Sci. China Earth Sci. 59, 2328-2338. doi: 10.1007/s11430-015-5500-5

Chen, S.-H., and Wu, J.-T. (1999). Paleolimnological environment indicated by the diatom and pollen assemblages in an alpine lake in Taiwan. J. Paleolimnol. 22, 149-158. doi: 10.1023/A:1008067928365

Cheng, H., Edwards, R. L., Broecker, W. S., Denton, G. H., Kong, X., Wang, Y., et al. (2009). Ice age terminations. Science 326, 248-252. doi: 10.1126/science. 1177840

Cheng, H., Edwards, R. L., Sinha, A., Spotl, C., Yi, L., Chen, S., et al. (2016). The Asian monsoon over the past 640,000 years and ice age terminations. Nature 534, 640-646. doi: 10.1038/nature18591

Cheng, H., Zhang, H., Zhao, J., Li, H., Ning, Y., and Kathayat, G. (2019). Chinese stalagmite paleoclimate researches: a review and perspective. Sci. China Earth Sci. 62, 1-25. doi: 10.1007/s11430-019-9478-3

Chiang, J. C. H., Fung, I. Y., Wu, C.-H., Cai, Y., Edman, J. P., Liu, Y., et al. (2015). Role of seasonal transitions and westerly jets in East Asian paleoclimate. Quat. Sci. Rev. 108, 111-129. doi: 10.1016/j.quascirev.2014.11.009

Conroy, J., Overpeck, J., Cole, J., Shanahan, T., and Steinitz-Kannan, M. (2008). Holocene changes in eastern tropical Pacific climate inferred from a Galápagos lake sediment record. Quat. Sci. Rev. 27, 1166-1180.

Dadson, S. J., Hovius, N., Chen, H., Dade, W. B., Hsieh, M.-L., Willett, S. D., et al. (2003). Links between erosion, runoff variability and seismicity in the Taiwan orogen. Nature 426, 648-651. doi: 10.1038/nature02150

Ding, X., Bao, H., Zheng, L., Li, D., and Kao, S. J. (2017). Lacustrine lignin biomarker record reveals a severe drought during the late Younger Dryas in southern Taiwan. J. Asian Earth Sci. 135, 281-290. doi: 10.1016/j.jseaes.2017. 01.003

Ding, X., Zheng, L., Li, D., Yang, T.-N., Lee, T.-Q., and Kao, S.-J. (2016). Lacustrine record of centennial-and millennial-scale rainfall variability of the East Asian summer monsoon during the last deglaciation: multi-proxy evidence from Taiwan. Palaeogeogr. Palaeoclimatol. Palaeoecol. 450, 38-49. doi: 10.1016/j. palaeo.2016.02.048

Ding, Y., and Chan, J. (2005). The East Asian summer monsoon: an overview. Meteorol. and Atmos. Phys. 89, 117-142. doi: 10.1007/s00703-005-0125-z

Dong, J., Wang, Y., Cheng, H., Hardt, B., Edwards, R. L., Kong, X., et al. (2010) A high-resolution stalagmite record of the Holocene East Asian monsoon from Mt Shennongia, central China. Holocnene 20, 257-264. doi: 10.1177/ 0959683609350393

Dykoski, C. A., Edwards, R. L., Cheng, H., Yuan, D., Cai, Y., Zhang, M., et al. (2005). A high-resolution, absolute-dated Holocene and deglacial Asian monsoon record from Dongge Cave. China. Earth Planet. Sci. Lett. 233, 71-86. doi: 10.1016/j.epsl.2005.01.036

Fleitmann, D. (2003). Holocene Forcing of the Indian Monsoon Recorded in a Stalagmite from Southern Oman. Science 300, 1737-1739. doi: 10.1126/science. 1083130
Goldsmith, Y., Broecker, W. S., Xu, H., Polissar, P. J., Porat, N., Lan, J., et al. (2017). Northward extent of East Asian monsoon covaries with intensity on orbital and millennial timescales. Proc. Natl. Acad. Sci. U.S.A. 114, 1817-1821. doi: 10.1073/pnas.1616708114

Guo, L., Xiong, S., Ding, Z., Jin, G. Y., Wu, J., and Ye, W. (2018). Role of the midHolocene environmental transition in the decline of late Neolithic cultures in the deserts of NE China. Quat. Sci. Rev. 190, 98-113. doi: 10.1016/j.quascirev. 2018.04.017

Guo, Z., Biscaye, P., Wei, L., Chen, X., Peng, S., and Liu, T. J. G. R. L. (2000). Summer monsoon variations over the last $1.2 \mathrm{Ma}$ from the weathering of loess-soil sequences in China. Geophys. Res. Lett. 27, 1751-1754. doi: 10.1029/ 1999GL008419

Haug, G. H., Hughen, K. A., Sigman, D. M., Peterson, L. C., and Röhl, U. (2001). Southward migration of the intertropical convergence zone through the Holocene. Science 293, 1304-1308. doi: 10.1126/science.105 9725

Hong, Y. T., Hong, B., Lin, Q. H., Shibata, Y., Hirota, M., Zhu, Y. X., et al. (2005). Inverse phase oscillations between the East Asian and Indian Ocean summer monsoons during the last 12000 years and paleo-El Niño. Earth Planet. Sci. Lett. 231, 337-346. doi: 10.1016/j.epsl.2004.12.025

Hsieh, M.-L., Ching, K.-E., Chyi, S.-J., Kang, S.-C., and Chou, C.-Y. (2014). Late Quaternary mass-wasting records in the actively uplifting Pa-chang catchment, southwestern Taiwan. Geomorphology 216, 125-140. doi: 10.1016/j.geomorph. 2014.03.040

Hsieh, M.-L., and Chyi, S.-J. (2010). Late Quaternary mass-wasting records and formation of fan terraces in the Chen-yeo-lan and Lao-nung catchments, central-southern Taiwan. Quat. Sci. Rev. 29, 1399-1418. doi: 10.1016/j. quascirev.2009.10.002

Hsieh, M.-L., Lai, L. S.-H., Lin, C. D.-J., and Shyu, J. B. H. (2012). Late Quaternary landscape evolution and genesis of the 2009 catastrophic landslide in the Hsiaolin area, southwestern Taiwan. Geomorphology 179, 225-239. doi: 10.1016/j. geomorph.2012.08.014

Hsieh, M.-L., Liew, P.-M., and Chen, H.-W. (2011). Early Holocene catastrophic mass-wasting event and fan-delta development on the Hua-tung coast, eastern Taiwan. Geomorphology 134, 378-393. doi: 10.1016/j.geomorph.2011. 07.012

Hu, C., Henderson, G. M., Huang, J., Xie, S., Sun, Y., and Johnson, K. R. (2008). Quantification of Holocene Asian monsoon rainfall from spatially separated cave records. Earth Planet. Sci. Lett. 266, 221-232. doi: 10.1016/j.epsl.2007. 10.015

Huang, C., Zeng, T., Ye, F., Xie, L., Wang, Z., Wei, G., et al. (2018). Natural and anthropogenic impacts on environmental changes over the past 7500 years based on the multi-proxy study of shelf sediments in the northern South China Sea. Quat. Sci. Rev. 197, 35-48. doi: 10.1016/j.quascirev.2018.08.005

Huang, X., Pancost, R. D., Xue, J., Gu, Y., Evershed, R. P., and Xie, S. (2018). Response of carbon cycle to drier conditions in the mid-Holocene in central China. Nat. comm. 9, 1-9. doi: 10.1038/s41467-018-03804-w

Ishii, Y. (2018). Middle to late Holocene delta plain evolution of the Kimotsuki lowland. Kyushu (southern Japan). Palaeogeogr. Palaeoclimatol. Palaeoecol. 502, 74-85. doi: 10.1016/j.palaeo.2018.04.025

Jeng, W. L., and Kao, S. J. (2002). Lipids in suspended matter from the humandisturbed Lanyang River, northeastern Taiwan. Environ. Geol. 43, 138-144. doi: 10.1007/s00254-002-0619-7

Ji, J., Shen, J., Balsam, W., Chen, J., Liu, L., and Liu, X. (2005). Asian monsoon oscillations in the northeastern Qinghai-Tibet Plateau since the late glacial as interpreted from visible reflectance of Qinghai Lake sediments. Earth Planet. Sci. Lett. 233, 61-70. doi: 10.1016/j.epsl.2005.02.025

Jia, G., Bai, Y., Yang, X., Xie, L., Wei, G., Ouyang, T., et al. (2015). Biogeochemical evidence of Holocene East Asian summer and winter monsoon variability from a tropical maar lake in southern China. Quat. Sci. Rev. 111, 51-61. doi: 10.1016/ j.quascirev.2015.01.002

Jian, Z., Wang, P., Saito, Y., Wang, J., Pflaumann, U., Oba, T., et al. (2000). Holocene variability of the Kuroshio current in the Okinawa Trough, northwestern Pacific Ocean. Earth Planet. Sci. Lett. 184, 305-319. doi: 10.1016/ S0012-821X(00)00321-6

Jiang, D., Lang, X., Tian, Z., and Ju, L. (2013). Mid-Holocene East Asian summer monsoon strengthening: insights from Paleoclimate Modeling Intercomparison 
Project (PMIP) simulations. Palaeogeogr. Palaeoclimatol. Palaeoecol. 369, 422429. doi: 10.1016/j.palaeo.2012.11.007

Kong, W., Swenson, L. M., and Chiang, J. C. H. (2017). Seasonal Transitions and the Westerly Jet in the Holocene East Asian Summer Monsoon. J. Climate 30, 3343-3365. doi: 10.1175/JCLI-D- 16-0087.1

Lee, C.-Y., and Liew, P.-M. (2010). Late Quaternary vegetation and climate changes inferred from a pollen record of Dongyuan Lake in southern Taiwan. Palaeogeogr. Palaeoclimatol. Palaeoecol. 287, 58-66. doi: 10.1016/j.palaeo.2010. 01.015

Lee, C. Y., Liew, P. M., and Lee, T. Q. (2010). Pollen records from southern Taiwan: implications for East Asian summer monsoon variation during the Holocene. Holocene 20, 81-89. doi: 10.1177/0959683609348859

Li, J., Dodson, J., Yan, H., Wang, W., Innes, J. B., Zong, Y., et al. (2018). Quantitative Holocene climatic reconstructions for the lower Yangtze region of China. Clim. Dyn. 50, 1101-1113. doi: 10.1007/s00382-017-3664-3

Li, Q., Wu, H., Yu, Y., Sun, A., Marković, S. B., Guo, Z. J. G., et al. (2014). Reconstructed moisture evolution of the deserts in northern China since the Last Glacial Maximum and its implications for the East Asian Summer Monsoon. Glob. Planet. Change 121, 101-112. doi: 10.1016/j.gloplacha.2014. 07.009

Liew, P.-M., and Huang, S.-Y. (1994). A 5000-year pollen record from Chitsai Lake, central Taiwan. Terr. Atmos. Oceanic Sci. 5, 411-419. doi: 10.3319/TAO.1994.5. 3.411(PAGES)

Liew, P. M., Lee, C. Y., and Kuo, C. M. (2006). Holocene thermal optimal and climate variability of East Asian monsoon inferred from forest reconstruction of a subalpine pollen sequence. Taiwan. Earth Planet. Sci. Lett. 250, 596-605. doi: 10.1016/j.epsl.2006.08.002

Liew, P.-M., Wu, M.-H., Lee, C.-Y., Chang, C.-L., and Lee, T.-Q. (2014). Recent 4000 years of climatic trends based on pollen records from lakes and a bog in Taiwan. Quat. Int. 349, 105-112. doi: 10.1016/j.quaint.2014.05.018

Liu, H., Gu, Y., Huang, X., Yu, Z., Xie, S., and Cheng, S. (2019). A 13,000-year peatland palaeohydrological response to the ENSO-related Asian monsoon precipitation changes in the middle Yangtze Valley. Quat. Sci. Rev. 212, 80-91. doi: 10.1016/j.quascirev.2019.03.034

Liu, J., Chen, J., Zhang, X., Li, Y., Rao, Z., and Chen, F. (2015). Holocene East Asian summer monsoon records in northern China and their inconsistency with Chinese stalagmite $\delta 18$ O records. Earth-Sci. Rev. 148, 194-208. doi: 10. 1016/j.earscirev.2015.06.004

Liu, Z., Lu, Z., Wen, X., Otto-Bliesner, B. L., Timmermann, A., and Cobb, K. M. (2014a). Evolution and forcing mechanisms of El Nino over the past 21,000 years. Nature 515, 550-553. doi: 10.1038/nature 13963

Liu, Z., Wen, X., Brady, E. C., Otto-Bliesner, B., Yu, G., Lu, H., et al. (2014b). Chinese cave records and the East Asia Summer Monsoon. Quat. Sci. Rev. 83, 115-128. doi: 10.1016/j.quascirev.2013.10.021

Liu, Z., Otto-Bliesner, B. L., He, F., Brady, E. C., Tomas, R., Clark, P. U., et al. (2009). Transient simulation of last deglaciation with a new mechanism for Bølling-Allerød warming. Science 325, 310-314. doi: 10.1126/science.1171041

Liu, Z., Trentesaux, A., Clemens, S. C., Colin, C., Wang, P., Huang, B., et al. (2003). Clay mineral assemblages in the northern South China Sea: implications for East Asian monsoon evolution over the past 2 million years. Mar. Geol. 201, 133-146. doi: 10.1016/S0025-3227(03)00213-5

Lu, F., Ma, C., Zhu, C., Lu, H., Zhang, X., Huang, K., et al. (2019). Variability of East Asian summer monsoon precipitation during the Holocene and possible forcing mechanisms. Clim. Dyn. 52, 969-989. doi: 10.1007/s00382-018-4175-6

Lu, H., Yi, S., Liu, Z., Mason, J. A., Jiang, D., Cheng, J., et al. (2013). Variation of East Asian monsoon precipitation during the past 21 k.y. and potential $\mathrm{CO} 2$ forcing. Geology 41, 1023-1026. doi: 10.1130/g34488.1

Maher, B. A. (2008). Holocene variability of the East Asian summer monsoon from Chinese cave records: a re-assessment. Holocene 18, 861-866. doi: 10.1177/ 0959683608095569

Maher, B. A., and Thompson, R. (2012). Oxygen isotopes from Chinese caves: records not of monsoon rainfall but of circulation regime. J. Quat. Sci. 27, 615-624. doi: 10.1002/jqs.2553

McGee, D., Donohoe, A., Marshall, J., and Ferreira, D. (2014). Changes in ITCZ location and cross-equatorial heat transport at the Last Glacial Maximum, Heinrich Stadial 1, and the mid-Holocene. Earth Planet. Sci. Lett. 390, 69-79. doi: 10.1016/j.epsl.2013.12.043
McManus, J., Francois, R., Gherardi, J.-M., Keigwin, L., and Brown-Leger, S. (2004). Collapse and rapid resumption of Atlantic meridional circulation linked to deglacial climate changes. Nature 428, 834-837. doi: 10.1038/nature02494

Meng, X., Liu, L., Wang, X. T., Balsam, W., Chen, J., Ji, J. J. E., et al. (2018). Mineralogical evidence of reduced East Asian summer monsoon rainfall on the Chinese loess plateau during the early Pleistocene interglacials. Earth Planet. Sci. Lett. 486, 61-69. doi: 10.1016/j.epsl.2017.12.048

Milliman, J. D., and Kao, S.-J. (2005). Hyperpycnal discharge of fluvial sediment to the ocean: impact of super-typhoon Herb (1996) on Taiwanese rivers. J. Geol. 113, 503-516. doi: 10.1086/431906

Ming, G., Zhou, W., Wang, H., Cheng, P., Shu, P., Xian, F., et al. (2020). Moisture variations in Lacustrine-eolian sequence from the Hunshandake sandy land associated with the East Asian Summer Monsoon changes since the late Pleistocene. Quat. Sci. Rev. 233:106210. doi: 10.1016/j.quascirev.2020.106210

Park, J., Shin, Y. H., and Byrne, R. (2016). Late-Holocene vegetation and climate change in Jeju Island. Korea and its implications for ENSO influences. Quat. Sci. Rev. 153, 40-50. doi: 10.1016/j.quascirev.2016.10.011

Pausata, F. S. R., Battisti, D. S., Nisancioglu, K. H., and Bitz, C. M. (2011). Chinese stalagmite $\delta 18 \mathrm{O}$ controlled by changes in the Indian monsoon during a simulated Heinrich event. Nat. Geosci. 4, 474-480. doi: 10.1038/ngeo1169

Putnam, A. E., and Broecker, W. S. (2017). Human-induced changes in the distribution of rainfall. Sci. Adv. 3:e1600871. doi: 10.1126/sciadv.1600871

Rao, Z., Li, Y., Zhang, J., Jia, G., and Chen, F. (2016). Investigating the longterm palaeoclimatic controls on the $\delta \mathrm{D}$ and $\delta 18 \mathrm{O}$ of precipitation during the Holocene in the Indian and East Asian monsoonal regions. Earth-Sci. Rev. 159, 292-305. doi: 10.1016/j.earscirev.2016.06.007

Rein, B. (2007). How do the $1982 / 83$ and $1997 / 98$ El Niños rank in a geological record from peru? Quat. Int. 161, 56-66. doi: 10.1016/j.quaint.2006.10.023

Renssen, H., Seppä, H., Crosta, X., Goosse, H., and Roche, D. (2012). Global characterization of the Holocene Thermal Maximum. Quat. Sci. Rev. 48, 7-19. doi: 10.1016/j.quascirev.2012.05.022

Rind, D. (1998). Latitudinal temperature gradients and climate change. J. Geophys. Res-Atmos. 103, 5943-5971. doi: 10.1029/97JD03649

Selvaraj, K., Chen, C. T. A., and Lou, J. Y. (2007). Holocene East Asian monsoon variability: links to solar and tropical Pacific forcing. Geophys. Res. Lett. 34:L01703. doi: 10.1029/2006GL028155

Selvaraj, K., Chen, C. T. A., Lou, J.-Y., and Kotlia, B. S. (2011). Holocene weak summer East Asian monsoon intervals in Taiwan and plausible mechanisms. Quat. Int. 229, 57-66. doi: 10.1016/j.quaint.2010.01.015

Selvaraj, K., Wei, K.-Y., Liu, K.-K., and Kao, S.-J. (2012). Late Holocene monsoon climate of northeastern Taiwan inferred from elemental (C, N) and isotopic ( $813 \mathrm{C}, 815 \mathrm{~N})$ data in lake sediments. Quat. Sci. Rev. 37, 48-60. doi: 10.1016/ j.quascirev.2012.01.009

Shanahan, T., McKay, N., Hughen, K., Overpeck, J., Otto-Bliesner, B., Heil, C., et al. (2015). The time-transgressive termination of the African Humid Period. Nat. Geo. 8, 140-144. doi: 10.1038/ngeo2329

Sheng, M., Wang, X., Zhang, S., Chu, G., Su, Y., and Yang, Z. (2017). A 20,000year high-resolution pollen record from Huguangyan Maar Lake in tropicalsubtropical South China. Palaeogeogr. Palaeoclimatol. Palaeoecol. 472, 83-92. doi: 10.1016/j.palaeo.2017.01.038

Shi, Z., Liu, X., and Cheng, X. (2012). Anti-phased response of northern and southern East Asian summer precipitation to ENSO modulation of orbital forcing. Quat. Sci. Rev. 40, 30-38. doi: 10.1016/j.quascirev.2012.02.019

Stott, L., Cannariato, K., Thunell, R., Haug, G. H., Koutavas, A., and Lund, S. (2004). Decline of surface temperature and salinity in the western tropical Pacific Ocean in the Holocene epoch. Nature 431, 56-59. doi: 10.1038/ nature 02903

Sun, A., and Feng, Z. (2013). Holocene climatic reconstructions from the fossil pollen record at Qigai Nuur in the southern Mongolian Plateau. Holocene 23, 1391-1402. doi: 10.1177/0959683613489581

Sun, X., Luo, Y., Huang, F., Tian, J., and Wang, P. (2003). Deep-sea pollen from the South China Sea: pleistocene indicators of East Asian monsoon. Mar. Geol. 201, 97-118. doi: 10.1016/s0025-3227(03)00211-1

Sun, Y., Clemens, S. C., An, Z., and Yu, Z. (2006). Astronomical timescale and palaeoclimatic implication of stacked 3.6-Myr monsoon records from the Chinese Loess Plateau. Quat. Sci. Rev. 25, 33-48. doi: 10.1016/j.quascirev.2005. 07.005 
Sun, Y., Kutzbach, J., An, Z., Clemens, S., Liu, Z., Liu, W., et al. (2015). Astronomical and glacial forcing of East Asian summer monsoon variability. Quat. Sci. Rev. 115, 132-142. doi: 10.1016/j.quascirev.2015.03.009

Tan, M. (2014). Circulation effect: response of precipitation $\delta 180$ to the ENSO cycle in monsoon regions of China. Clim. Dyn. 42, 1067-1077. doi: 10.1007/ s00382-013-1732-x

Toggweiler, J. R. (2009). Shifting Westerlies. Science 323, 1434-1435. doi: 10.1126/ science. 1169823

Toth, L. T., Aronson, R. B., Vollmer, S. V., Hobbs, J. W., Urrego, D. H., Cheng, H., et al. (2012). ENSO drove 2500-year collapse of eastern Pacific coral reefs. Science 337, 81-84. doi: 10.1126/science. 1221168

Wan, S., Tian, J., Steinke, S., Li, A., and Li, T. (2010). Evolution and variability of the East Asian summer monsoon during the Pliocene: evidence from clay mineral records of the South China Sea. Palaeogeogr. Palaeoclimatol. Palaeoecol. 293, 237-247. doi: 10.1016/j.palaeo.2010.05.025

Wang, B., Wu, Z. W., Li, J., Liu, J., Chang, C., Ding, Y., et al. (2008). How to measure the strength of the East Asian summer monsoon? J. Climate 21, 4449-4463. doi: 10.1175/2008JCLI2183.1

Wang, H., Chen, J., Zhang, X., and Chen, F. (2014). Palaeosol development in the Chinese Loess Plateau as an indicator of the strength of the East Asian summer monsoon: evidence for a mid-Holocene maximum. Quat. Int. 33, 155-164. doi: 10.1016/j.quaint.2014.03.013

Wang, L.-C., Behling, H., Chen, Y.-M., Huang, M.-S., Arthur Chen, C.-T., Lou, J.-Y., et al. (2014). Holocene monsoonal climate changes tracked by multiproxy approach from a lacustrine sediment core of the subalpine Retreat Lake in Taiwan. Quat. Int. 333, 69-76. doi: 10.1016/j.quaint.2014. 02.014

Wang, L., Sarnthein, M., Erlenkeuser, H., Grimalt, J., Grootes, P., Heilig, S., et al. (1999). East Asian monsoon climate during the Late Pleistocene: highresolution sediment records from the South China Sea. Mar. Geol. 156, 245-284. doi: 10.1016/s0025-3227(98)00182-0

Wang, L.-C., Behling, H., Kao, S.-J., Li, H.-C., Selvaraj, K., Hsieh, M.-L., et al. (2015). Late Holocene environment of subalpine northeastern Taiwan from pollen and diatom analysis of lake sediments. J. Asian Earth Sci. 114, 447-456. doi: 10.1016/j.jseaes.2015.03.037

Wang, P. X., Wang, B., Cheng, H., Fasullo, J., Guo, Z., Kiefer, T., et al. (2017). The global monsoon across time scales: mechanisms and outstanding issues. Earth-Sci. Rev. 174, 84-121. doi: 10.1016/j.earscirev.2017.07.006

Wang, S.-Y., and Chen, T.-C. (2008). Measuring East Asian summer monsoon rainfall contributions by different weather systems over Taiwan. J. Appl. Meteorol. Clim. 47, 2068-2080. doi: 10.1175/2007jamc1821.1

Wang, W., and Feng, Z. D. (2013). Holocene moisture evolution across the Mongolian Plateau and its surrounding areas: a synthesis of climatic records. Earth Sci. Rev. 122, 38-57. doi: 10.1016/j.earscirev.2013.03.005

Wang, X., Chu, G., Sheng, M., Zhang, S., Li, J., Chen, Y., et al. (2016). Millennial-scale Asian summer monsoon variations in South China since the last deglaciation. Earth Planet. Sci. Lett. 451, 22-30. doi: 10.1016/j.epsl.2016. 07.006

Wang, Y., Cheng, H., Edwards, R. L., An, Z., Wu, J., Shen, C.-C., et al. (2001). A high-resolution absolute-dated late Pleistocene monsoon record from Hulu Cave. China. Science 294, 2345-2348. doi: 10.1126/science.1064618

Wang, Y., Cheng, H., Edwards, R. L., He, Y., Kong, X., An, Z., et al. (2005). The Holocene Asian monsoon: links to solar changes and North Atlantic climate. Science 308, 854-857. doi: 10.1126/science.1106296

Wenske, D., Böse, M., Frechen, M., and Lüthgens, C. (2011). Late Holocene mobilisation of loess-like sediments in Hohuan Shan, high mountains of Taiwan. Quat. Int. 234, 174-181. doi: 10.1016/j.quaint.2009. 10.034

Wu, C. (2013). Holocene Sedimentation on the Lanyang Plain and Adjacent Continental Shelf, Northwestern Taiwan. Dissertations/master's thesis, College of William \& Mary, Virginia, doi: 10.25773/v5-v8ng-wk84

Xiao, J., Wu, J., Si, B., Liang, W., Nakamura, T., Liu, B., et al. (2006). Holocene climate changes in the monsoon/arid transition reflected by carbon concentration in Daihai Lake of Inner Mongolia. Holocene 16, 551-560. doi: 10.1191/0959683606hl950rp

Xie, S., Evershed, R. P., Huang, X., Zhu, Z., Pancost, R. D., Meyers, P. A., et al. (2013). Concordant monsoon-driven postglacial hydrological changes in peat and stalagmite records and their impacts on prehistoric cultures in central China. Geology 41, 827-830. doi: 10.1130/G34318.1

Xu, H., Goldsmith, Y., Lan, J., Tan, L., Wang, X., Zhou, X., et al. (2020). Juxtaposition of western Pacific subtropical high on Asian Summer Monsoon shapes subtropical East Asian precipitation. Geophys. Res. Lett. 47:e2019GL084705. doi: 10.1029/2019GL084705

Xu, H., Lan, J., Sheng, E., Liu, B., Yu, K., Ye, Y., et al. (2016). Hydroclimatic contrasts over Asian monsoon areas and linkages to tropical Pacific SSTs. Sci. Rep. 6:33177. doi: 10.1038/srep33177

Xu, H., Song, Y. P., Goldsmith, Y., and Lang, Y. C. (2019). Meridional ITCZ shifts modulate tropical/subtropical Asian monsoon rainfall. Sci. Bull. 64, 1737-1739. doi: 10.1016/j.scib.2019.09.025

Yancheva, G., Nowaczyk, N. R., Mingram, J., Dulski, P., Schettler, G., Negendank, J. F., et al. (2007). Influence of the intertropical convergence zone on the East Asian monsoon. Nature 445, 74-77. doi: 10.1038/nature05431

Yang, T.-N., Lee, T.-Q., Meyers, P. A., Song, S.-R., Kao, S.-J., Löwemark, L., et al. (2011). Variations in monsoonal rainfall over the last $21 \mathrm{kyr}$ inferred from sedimentary organic matter in Tung-Yuan Pond, southern Taiwan. Quat. Sci. Rev. 30, 3413-3422. doi: 10.1016/j.quascirev.2011.08.017

Yang, X., Yang, H., Wang, B., Huang, L.-J., Shen, C.-C., Edwards, R. L., et al. (2019). Early-Holocene monsoon instability and climatic optimum recorded by Chinese stalagmites. Holocene 29, 1059-1067. doi: 10.1177/0959683619831433

Yuan, D., Cheng, H., Edwards, R. L., Dykoski, C. A., Kelly, M. J., Zhang, M., et al. (2004). Timing, duration, and transitions of the last interglacial Asian monsoon. Science 304, 575-578. doi: 10.1126/science. 1091220

Zhang, E., Zhao, C., Xue, B., Liu, Z., Yu, Z., Chen, R., et al. (2017). Millennial-scale hydroclimate variations in southwest China linked to tropical Indian Ocean since the Last Glacial Maximum. Geology 45, 435-438. doi: 10.1130/G38309.1

Zhang, H., Ait Brahim, Y., Li, H., Zhao, J., Kathayat, G., Tian, Y., et al. (2019). The Asian summer monsoon: Teleconnections and forcing mechanisms-A review from Chinese speleothem $\delta 18 \mathrm{O}$ records. Quaternary 2:26. doi: 10.3390/ quat 2030026

Zhang, H., Griffiths, M. L., Chiang, J. C., Kong, W., Wu, S., Atwood, A., et al. (2018). East Asian hydroclimate modulated by the position of the westerlies during Termination I. Science 362, 580-583. doi: 10.1126/science.aat9393

Zhao, C., Chang, Y. P., Chen, M. T., and Liu, Z. (2013). Possible reverse trend in Asian summer monsoon strength during the late Holocene. J. Asian Earth Sci. 69, 102-112. doi: 10.1016/j.jseaes.2012.09.028

Zhong, W., Xue, J., Zheng, Y., Ouyang, J., Ma, Q., Cai, Y., et al. (2010). Climatic changes since the last deglaciation inferred from a lacustrine sedimentary sequence in the eastern Nanling Mountains, south China. J. Quat Sci. 25, 975-984. doi: 10.1002/jqs.1384

Zhou, W., Yu, X., Jull, A. J. T., Burr, G., Xiao, J. Y., Lu, X., et al. (2004). Highresolution evidence from southern China of an early Holocene optimum and a mid-Holocene dry event during the past 18,000 years. Quat. Res. 62, 39-48. doi: 10.1016/j.yqres.2004.05.004

Zhou, X., Sun, L., Zhan, T., Huang, W., Zhou, X., Hao, Q., et al. (2016). Timetransgressive onset of the Holocene Optimum in the East Asian monsoon region. Earth Planet. Sci. Lett. 456, 39-46. doi: 10.1016/j.epsl.2016.09.052

Zhu, C., Ma, C., YU, S. Y., Tang, L., Zhang, W., and Lu, X. (2010). A detailed pollen record of vegetation and climate changes in Central China during the past 16 000 years. Boreas 39, 69-76. doi: 10.1111/j.1502-3885.2009.00098.x

Zhu, Z., Feinberg, J. M., Xie, S., Bourne, M. D., Huang, C., Hu, C., et al. (2017). Holocene ENSO-related cyclic storms recorded by magnetic minerals in speleothems of central China. Proc. Natl. Acad. Sci. U.S.A. 114, 852-857. doi: $10.1073 /$ pnas. 1610930114

Conflict of Interest: The authors declare that the research was conducted in the absence of any commercial or financial relationships that could be construed as a potential conflict of interest.

Copyright (c) 2020 Ding, Zheng, Zheng and Kao. This is an open-access article distributed under the terms of the Creative Commons Attribution License (CC BY). The use, distribution or reproduction in other forums is permitted, provided the original author(s) and the copyright owner(s) are credited and that the original publication in this journal is cited, in accordance with accepted academic practice. No use, distribution or reproduction is permitted which does not comply with these terms. 